\title{
Eighty Years of Mycopathologia: A Retrospective Analysis of Progress Made in Understanding Human and Animal Fungal Pathogens
}

\author{
Vishnu Chaturvedi · Jean-Philippe Bouchara - Ferry Hagen • Ana Alastruey-Izquierdo • \\ Hamid Badali - Anamelia Lorenzetti Bocca $\cdot$ Jose F. Cano-Lira • \\ Cunwei Cao - Sudha Chaturvedi - Sanjay H. Chotirmall - Anne D. van Diepeningen - \\ Jean-Pierre Gangneux • Jesus Guinea $\cdot$ Sybren de Hoog • Macit Ilkit • \\ Rui Kano - Weida Liu • Nilce M. Martinez-Rossi - Marcia de Souza Carvalho Melhem • \\ Mario Augusto Ono - Yuping Ran - Stephane Ranque - Celia Maria de Almeida Soares • \\ Takashi Sugita $\cdot$ Philip A. Thomas • Anna Vecchiarelli $\cdot$ Nancy L. Wengenack • \\ Patrick C. Y. Woo $\cdot$ Jianping Xu $\cdot$ Rosely M. Zancope-Oliveira
}

Received: 9 November 2018/Accepted: 9 November 2018/Published online: 30 November 2018

(C) Springer Nature B.V. 2018

\begin{abstract}
Mycopathologia was founded in 1938 to 'diffuse the understanding of fungal diseases in man and animals among mycologists.' This was an important mission considering that pathogenic fungi for humans and animals represent a tiny minority of the estimated 1.5-5 million fungal inhabitants on Earth.
\end{abstract}

V. Chaturvedi $(\bowtie) \cdot$ S. Chaturvedi

New York State Department of Health and University at Albany, Albany, NY, USA

e-mail: eic@mycopathologia.net

S. Chaturvedi

e-mail: Sudha.Chaturvedi@health.ny.gov

J.-P. Bouchara

Université Bretagne-Loire, Angers, France

e-mail: Jean-Philippe.Bouchara@univ-angers.fr

F. Hagen - S. de Hoog

Westerdijk Fungal Biodiversity Institute, Utrecht, The

Netherlands

e-mail: f.hagen@westerdijkinstitute.nl

S. de Hoog

e-mail: s.hoog@westerdijkinstitute.nl

A. Alastruey-Izquierdo

Instituto Salud Carlos III, Madrid, Spain

e-mail: anaalastruey@isciii.es
These pathogens have diverged from the usual saprotrophic lifestyles of most fungi to colonize and infect humans and animals. Medical and veterinary mycology is the subdiscipline of microbiology that dwells into the mysteries of parasitic, fungal lifestyles. Among the oldest continuing scientific publications

\section{H. Badali \\ Mazandaran University of Medical Sciences, Sari, Iran e-mail: badali.youngisham@gmail.com}
A. L. Bocca
University of Brasilia (UnB), Brasíla, DF, Brazil
e-mail: albocca@unb.br
J. F. Cano-Lira
Universitat Rovira i Virgili, Reus, Spain
e-mail: jose.cano@urv.cat
C. Cao
Guangxi Medical University, Nanning, China
e-mail: caocunwei@yeah.net

\section{S. H. Chotirmall}
Lee Kong Chian School of Medicine, Singapore,
Singapore
e-mail: schotirmall@ntu.edu.sg 
on the subject, Mycopathologia had its share of 'classic papers' since the first issue was published in 1938. An analysis of the eight decades of notable contributions reveals many facets of host-pathogen interactions among 183 volumes comprising about 6885 articles. We have analyzed the impact and relevance of this body of work using a combination of citation tools (Google Scholar and Scopus) since no single citation metric gives an inclusive perspective. Among the highly cited Mycopathologia publications, those on experimental mycology accounted for the major part of the articles (36\%), followed by diagnostic mycology (16\%), ecology and epidemiology $(15 \%)$, clinical mycology (14\%), taxonomy and classification (10\%), and veterinary mycology (9\%). The first classic publication, collecting nearly 200 citations, appeared in 1957, while two articles published in 2010 received nearly 150 citations each, which is notable for a journal covering a highly specialized field of study. An empirical analysis of the publication trends suggests continuing interests in novel diagnostics, fungal pathogenesis, review of clinical diseases especially with relevance to the laboratory scientists, taxonomy and classification of fungal pathogens, fungal infections and carriage in pets and wildlife, and changing ecology and epidemiology of fungal diseases around the globe. We anticipate that emerging and re-emerging fungal

A. D. van Diepeningen

Wageningen University and Research, Wageningen, The Netherlands

e-mail: anne.vandiepeningen@wur.nl

\section{J.-P. Gangneux}

Université Rennes, Rennes, France

e-mail: jean-pierre.gangneux@univ-rennes1.fr

\section{J. Guinea}

Universidad Complutense, Madrid, Spain

e-mail: jguineaortega@yahoo.es

\section{Ilkit}

University of Çukurova, Adana, Turkey

e-mail: milkit@cu.edu.tr

\section{R. Kano}

Nihon University College of Bioresource Sciences,

Fujisawa, Japan

e-mail:kanou.rui@nihon-u.ac.jp

W. Liu

Peking Union Medical College, Nanjing, China

e-mail: liumyco@hotmail.com pathogens will continue to cause significant health burden in the coming decades. It remains vital that scientists and physicians continue to collaborate by learning each other's language for the study of fungal diseases, and Mycopathologia will strive to be their partner in this increasingly important endeavor to its 100th anniversary in 2038 and beyond.

\section{Introduction}

2018 marks the eightieth anniversary of the founding of Mycopathologia (Fig. 1). The founding editors Piero Redaelli and Raffaele Ciferri 'wanted to diffuse the understanding of fungal diseases in man and animals among mycologists' [1]. This was a critical mission considering that pathogenic fungi for humans and animals represent a tiny minority of the estimated 1.5-5 million fungal inhabitants on Earth [2]. These pathogens have diverged from the usual saprotrophic lifestyles of most fungi to colonize and infect human and animals. Medical and veterinary mycology is the subdiscipline of microbiology that deals with the mysteries of parasitic, fungal lifestyles. Much is now known about the etiology of fungal infections, and the diagnosis and treatment of fungal diseases due to the pioneering efforts of scientists and physicians. At the

N. M. Martinez-Rossi

Ribeirão Preto Medical School, University of São Paulo,

Ribeirão Preto, SP, Brazil

e-mail: nmmrossi@usp.br

M. de Souza Carvalho Melhem

Adolfo Lutz Institute, São Paulo, Brazil

e-mail: melhemmr@uol.com.br

M. A. Ono

State University of Londrina, Londrina, Brazil

e-mail: marioono@uel.br

Y. Ran

Sichuan University, Chengdu, China

e-mail: ranyuping@vip.sina.com

S. Ranque

Université Aix-Marseille, Marseille, France

e-mail: stephane.ranque@ap-hm.fr

C. M. de Almeida Soares

Universidade Federal de Goiás, Goiânia, Goiás, Brazil

e-mail: cmasoares@gmail.com 
beginning of the journal, the availability of expertise was patchy around the globe as were the resources, and the integration with related disciplines remains a work in progress. Mycopathologia, one of the oldest scientific publications on the subject, has served the discipline well by enhancing the awareness and understanding of pathogenic fungi for humans and animals.

In the early years, Mycopathologia was closely associated with a large group of physicians and scientists responsible for laying the foundation of the 'modern era of medical mycology.' Earlier articles by the two former editors-in-chief, commemorating the twenty-fifth and fiftieth anniversaries of Mycopathologia, respectively, detailed the unique personalities of the early editorial teams and the extraordinary challenges they faced during the war years [1]. The narrative style of these editorials gave a rare behind the scene look at the personalities who were crucial during the formative years of the journal. The commemorative approach was common to that of other journals, an excellent example being the writeup of Edsall about the founding of the Journal of Biological Chemistry and its association with key discoveries in the life sciences [3]. For the eightieth anniversary, we decided to follow a different path in the style, wherein the Management Science journal celebrated its fiftieth anniversary by measuring the journal's metrics [4].

We summarize the most cited publications from the last eight decades of Mycopathologia to gauge the progress made on understanding medically important fungi. We also examined whether the longevity of Mycopathologia has any implications, especially in an era of the phenomenal growth of new journals for

\section{T. Sugita}

Meiji Pharmaceutical University, Tokyo, Japan

e-mail: sugita@my-pharm.ac.jp

\section{P. A. Thomas}

Institute of Ophthalmology, Joseph Eye Hospital,

Tiruchirappalli, India

e-mail: Thomasdiagnosticcentre@gmail.com

\section{A. Vecchiarelli}

Università di Perugia, Perugia, Italy

e-mail: anna.vecchiarelli@unipg.it

\section{N. L. Wengenack}

Mayo Clinic, Rochester, MN, USA

e-mail: wengn@mayo.edu medically important fungi. Among the most common journal metrics, the impact factor (IF) and the total number of citations are widely used to gauge the impact on the field even though the citation counts remain an imperfect measurement [5]. We used two citation databases (Google Scholar and Scopus) to ensure good representations of the Mycopathologia articles [6]. This overview did not include non-English articles and articles describing mycotoxins and plant pathogenic fungi as they constitute a small proportion of nearly 6885 articles published in Mycopathologia.

\section{Distribution of High Citations}

We tallied 138 articles into six subcategories (Tables 1, 2) with fifty or more citations (Google Scholar or Scopus 1961-2018) (Tables 3, 4, 5, 6, 7, 8). The distribution of the articles was: experimental mycology (36\% articles), diagnostic mycology (16\%), ecology and epidemiology (15\%), clinical mycology $(14 \%)$, taxonomy and classification $(10 \%)$, and veterinary mycology (9\%) (Fig. 2). The geographic origin of highly cited articles showed that overwhelming numbers came from USA and Europe, which was especially true for the first 50 years of the journal (Fig. 3). Overall, twenty-five countries on four continents accounted for highly cited articles. This picture is evolving as the community and journal witness more contributions from parts of Africa, Asia, Australia, and South America.

Diagnostic Mycology

The challenges in diagnostic mycology received full attention in the initial issues of Mycopathologia with

\section{P. C. Y. Woo}

The University of Hong Kong, Pokfulam, Hong Kong

e-mail: pcywoo@hku.hk

J. Xu

McMaster University, Hamilton, ON, Canada

e-mail: jpxu@mcmaster.ca

R. M. Zancope-Oliveira

Fundação Oswaldo Cruz, Rio de Janeiro, Brazil

e-mail: rosely.zancope@ini.flocruz.br 
Fig. 1 Title page of the first issue of Mycopathologia from 1938
Vol. I

9. V. 1938

Pasc. 1

\title{
MYCOPATHOLOGIA \\ EDITORES:
}

\author{
R. CIFERRI et P. REDAELLI \\ Firenze \\ Pavia
}

\section{COLLABORATORES:}

F. de Almeid a, Saõ Paulo - A. Azzi, Torino-T. B enedek, Chicago - R. W. B en h a mew York - A. Carini, Saõ Paulo - A. L. Carrion, San Juan de Porto Rico - A. C a stellani, Roma - A. C a t an e i, Alger N. F. C o n a n t, Durham, N. C. - A. M. D a vid s o n, Winnipeg - C. W. Dodge, St. Louis, Mo. - C. W. E m m o n s. Washington, D.C. - G. F a l c h i, Pavia O. da Fon seca, Rio de Janeiro-I. Froil a n o d e M ello, Nova Goa (Indes Portugaises) - H. Gougerot, Paris - L. Grigoraki, Marseille - A. Guillermond, Paris-F.C. H arrison, Montreal-A. T. Henrici, Minneapolis, Minn. - T. K a m b a y a $\mathrm{h} \mathrm{i,} \mathrm{Tokyo} \mathrm{-} \mathrm{J.} \mathrm{E.} \mathrm{M} \mathrm{c} \mathrm{K} \mathrm{in} \mathrm{n}$ on, MontevideoO. de Magalhães, Bello Horizonte-D. S. Martin, Durham, N.C. - S. Milochevitch, Beograd - M. Moore, St. Louis, Mo. - P. Negroni, Buenos Aires - M. Ot a, Tokyo - G. Poll a coi, Pavia - V. Punt on i, Roma - F. Rix f ord, Los Angeles, Calif. - H. d a R o c h a L i m a, Saõ Paulo - A. Sartory, Strasbourg - R. Sartory, Strasbourg - R. V. Talice, Montevideo - I. Ch. Verbunt, Batavia - F. D. Weidman, Philadelphia, Pa. - J. Westerdijk, Baarn.

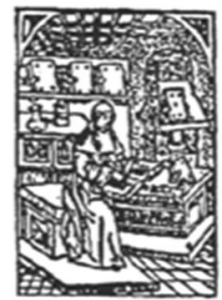

\begin{tabular}{lllllll}
\hline Dr. W. JUNK & - & UITGEVERIJ & - & DEN HAAG & - & 1938
\end{tabular}

the focus on the laboratory culture of oleaginous yeasts and the value of assimilation and fermentation tests for yeast identifications (Table 1) [7, 8]. Ajello and George [9] published the all-time classic in vitro hair perforation test for the laboratory differentiation of Trichophyton mentagrophytes from $T$. rubrum (Table 2). Nearly parallel to this discovery was the demonstration of the utility of monospecific antisera for laboratory identifications of yeasts by Tsuchiya et al. [10]. Further refinements of the serological methods were described such as micro-titration, immunoelectrophoresis, and ELISA (Tables 3, 4) [11-13]. The differentiation of fungal pathogens was refined by the applications of yeast killer toxins and 
Table 1 Most cited articles published in Mycopathologia 1938-1950

\begin{tabular}{|c|c|c|c|c|c|}
\hline & Title & Year & Subcategory & Citations $^{\mathrm{a}}$ & References \\
\hline 1 & The taxonomy of the anascosporous yeast-like fungi & 1939 & $\begin{array}{l}\text { Taxonomy \& } \\
\text { classification }\end{array}$ & $29 / 5$ & {$[120]$} \\
\hline 2 & Some notes on Torulopsis glabrata (Anderson) nov. comb. & 1938 & $\begin{array}{l}\text { Taxonomy \& } \\
\text { classification }\end{array}$ & $25 / 10$ & [121] \\
\hline 3 & $\begin{array}{l}\text { Trichophyton mentagrophytes (Pinoyella simii) isolated from } \\
\text { dermatophytosis in the monkey }\end{array}$ & 1939 & $\begin{array}{l}\text { Veterinary } \\
\text { mycology }\end{array}$ & $25 / 5$ & [131] \\
\hline 4 & On some sporogenous yeasts and their imperfect stages & 1940 & $\begin{array}{l}\text { Taxonomy \& } \\
\text { classification }\end{array}$ & $24 / 11$ & [122] \\
\hline 5 & $\begin{array}{l}\text { Cultivation of Malassezia furfur, etiological agent of pityriasis (tinea) } \\
\text { versicolor }\end{array}$ & 1938 & $\begin{array}{l}\text { Diagnostic } \\
\text { mycology }\end{array}$ & $20 / 8$ & [7] \\
\hline 6 & $\begin{array}{l}\text { An appeal for unification of the generic taxonomy in the } \\
\text { Mycotoruloideae }\end{array}$ & 1940 & $\begin{array}{l}\text { Taxonomy \& } \\
\text { classification }\end{array}$ & $16 / 5$ & [124] \\
\hline 7 & Torulopsis or Cryptococcus? & 1938 & $\begin{array}{l}\text { Taxonomy \& } \\
\text { classification }\end{array}$ & $14 / 6$ & [123] \\
\hline 8 & Biological significance of the pseudomycelium in asporogenous yeasts & 1943 & $\begin{array}{l}\text { Experimental } \\
\text { mycology }\end{array}$ & $7 / 3$ & {$[26]$} \\
\hline 9 & $\begin{array}{l}\text { Are fermentation tests and biochemical characteristics reliable in the } \\
\text { differentiation of monilias? }\end{array}$ & 1943 & $\begin{array}{l}\text { Diagnostic } \\
\text { mycology }\end{array}$ & $4 / 0$ & [8] \\
\hline 10 & $\begin{array}{l}\text { The classification of actinomycetes at the 3rd International Congress of } \\
\text { Microbiology }\end{array}$ & 1941 & $\begin{array}{l}\text { Taxonomy \& } \\
\text { classification }\end{array}$ & $2 / 44$ & [141] \\
\hline
\end{tabular}

${ }^{\text {a Google Scholar/Scopus }}$

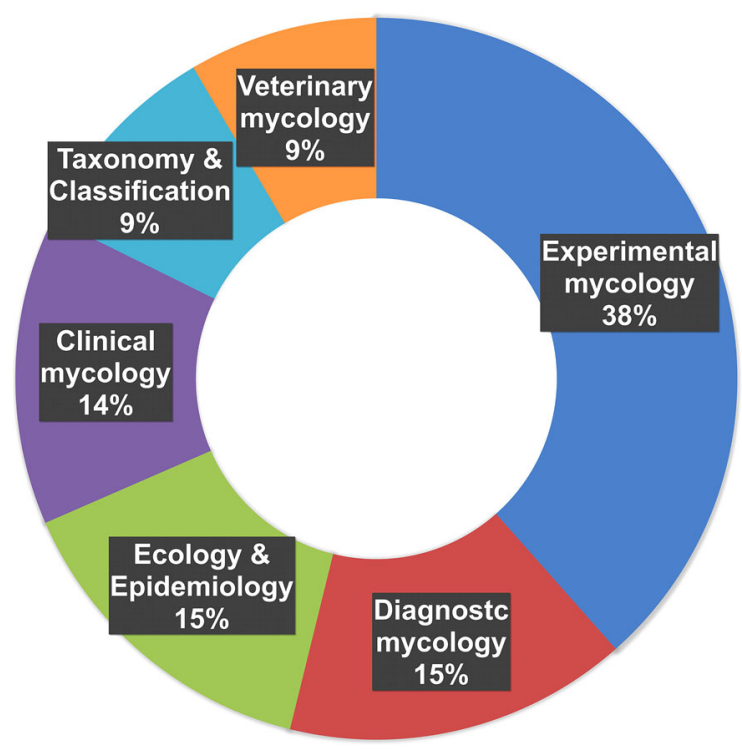

Fig. 2 Distribution of highly cited ( $>50$ citations in at least one database) publications from Mycopathologia (1961-2018)

species-specific exoantigens [14, 15]. Morisita et al. [16] described an early implementation of the cultureindependent, molecular diagnosis of pityriasis

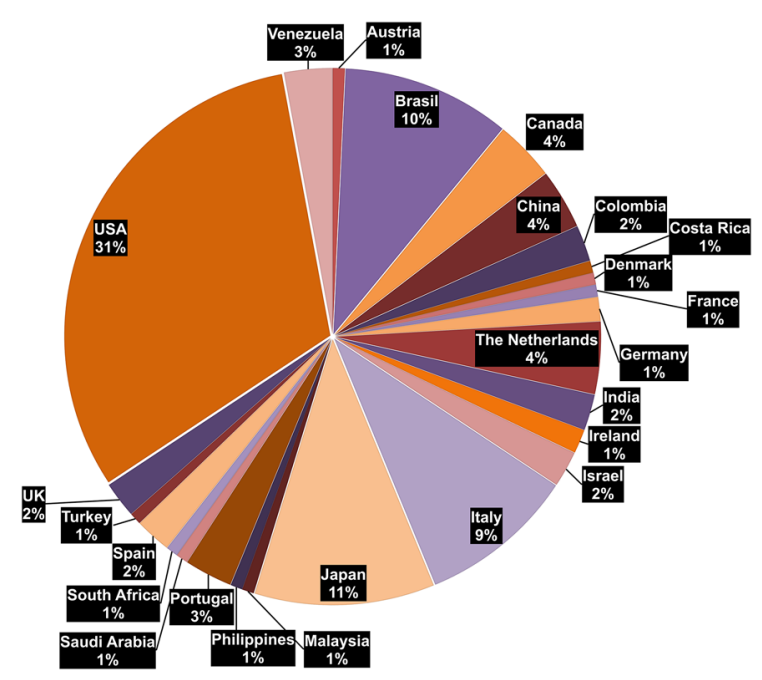

Fig. 3 Geographic distribution of most cited publications in Mycopathologia (1938-2018)

versicolor by deploying Malassezia species-specific nested PCR test. Another notable innovation was the application of mitochondrial DNA analysis for the typing of Sporothrix schenckii and related fungi 
Table 2 Most cited articles published in Mycopathologia 1951-1960

\begin{tabular}{|c|c|c|c|c|c|}
\hline & Title & Year & Subcategory & Citations $^{\mathrm{a}}$ & References \\
\hline 1 & $\begin{array}{l}\text { In vitro hair cultures for differentiating between atypical isolates of } \\
\text { Trichophyton mentagrophytes and Trichophyton rubrum }\end{array}$ & 1957 & $\begin{array}{l}\text { Diagnostic } \\
\text { mycology }\end{array}$ & $194 / 60$ & [9] \\
\hline 2 & $\begin{array}{l}\text { Isolation of Histoplasma capsulatum from an oil bird (Steatornis caripensis) } \\
\text { cave in Venezuela }\end{array}$ & 1960 & $\begin{array}{l}\text { Ecology \& } \\
\text { epidemiology }\end{array}$ & $64 / 17$ & [115] \\
\hline 3 & A method for the rapid identification of the genus Candida & 1959 & $\begin{array}{l}\text { Diagnostic } \\
\text { mycology }\end{array}$ & $61 / 20$ & {$[10]$} \\
\hline 4 & Cryptococcus neoformans strains from a severe outbreak of bovine mastitis & 1962 & $\begin{array}{l}\text { Veterinary } \\
\text { mycology }\end{array}$ & $41 / 7$ & [142] \\
\hline 5 & Candida albicans infections in actively and passively immunized animals & 1953 & $\begin{array}{l}\text { Experimental } \\
\text { mycology }\end{array}$ & $40 / 12$ & [41] \\
\hline 6 & Successful infection of pigeons and chickens with Histoplasma capsulatum & 1957 & $\begin{array}{l}\text { Experimental } \\
\text { mycology }\end{array}$ & $30 / 15$ & [40] \\
\hline 7 & Studies of the dimorphism mechanism in Saccharomyces cerevisiae & 1952 & $\begin{array}{l}\text { Experimental } \\
\text { mycology }\end{array}$ & $14 / 8$ & [57] \\
\hline 8 & The comparison of four strains of Coccidioides immitis with diverse histories & 1957 & $\begin{array}{l}\text { Experimental } \\
\text { mycology }\end{array}$ & $13 / 5$ & {$[42]$} \\
\hline 9 & $\begin{array}{l}\text { Effect of yeast extract, peptone, and certain nitrogen compounds on } \\
\text { sporulation of Saccharomyces cerevisiae }\end{array}$ & 1956 & $\begin{array}{l}\text { Experimental } \\
\text { mycology }\end{array}$ & $11 / 7$ & [58] \\
\hline 10 & $\begin{array}{l}\text { Inhibition of Histoplasma capsulatum and Blastomyces dermatitidis by } \\
\text { Pseudomonas aeruginosa in vitro }\end{array}$ & 1959 & $\begin{array}{l}\text { Experimental } \\
\text { mycology }\end{array}$ & $7 / 2$ & [27] \\
\hline
\end{tabular}

${ }^{\mathrm{a}}$ Google Scholar/Scopus

(Tables 5, 6) $[17,18]$. There were quite a few notable contributions on the laboratory susceptibility testing for antifungals and the relevance of molecular testing in the diagnostic laboratory (Tables 6, 7, 8) [19-22]. The description of new diagnostic technologies remains a favorite topic of Mycopathologia articles as the discipline moves into exciting areas such as whole genome sequencing, metagenomics, and proteomics [23-25].

\section{Experimental Mycology}

Experimental mycology included nearly one-third of all highly cited articles published in Mycopathologia starting with an article on yeast pseudomycelia in the very first issue (Table 1) [26]. The experimental results described in the journal covered all facets of medically important fungi and experimental disease models. Among the topics covered were antifungals and inhibitors [27-32], biofilms [33-39], immunity and virulence [25, 40-56], fungal structure, function, and nutrition [26, 57-67], and fungal metabolites and toxins [68-75]. The most common fungal pathogens investigated were Candida albicans and other Candida species followed by Aspergillus fumigatus, Paracoccidioides brasiliensis, Cryptococcus neoformans, Blastomyces dermatitidis, Histoplasma capsulatum, Coccidioides immitis, Saccharomyces cerevisiae, Malassezia species, Rhizopus species, Sporothrix species, and Stachybotrys species. These extensive collections of highly cited publications contain the reports of many trailblazing discoveries. Among the most remarkable publications in experimental mycology was the discovery of a linkage between $C$. albicans proteolysis and virulence by Staib (Table 3) [76]. Candida proteases are now widely recognized as crucial elements in the infectious processes [77, 78]. Similarly, Buffo et al. [63] described how temperature and $\mathrm{pH}$ regulate $C$. albicans yeast-hyphae transitions (Table 5). The Soll laboratory went on to discover the white-opaque colony phenotype switching, an important developmental pathway with crucial roles in the pathogenesis of candidiasis [79]. 
Table 3 Most cited articles published in Mycopathologia 1961-1970

\begin{tabular}{|c|c|c|c|c|c|}
\hline & Title & Year & Subcategory & Citations $^{\mathrm{a}}$ & References \\
\hline 1 & Proteolysis and pathogenicity of Candida albicans strains & 1969 & $\begin{array}{l}\text { Experimental } \\
\text { mycology }\end{array}$ & $108 / 33$ & [76] \\
\hline 2 & A taxonomic study in the "black yeasts" & 1962 & $\begin{array}{l}\text { Taxonomy \& } \\
\text { classification }\end{array}$ & $104 / 49$ & [126] \\
\hline 3 & $\begin{array}{l}\text { Relation of the pigeon to cryptococcosis: natural carrier state, heat } \\
\text { resistance and survival of Cryptococcus neoformans }\end{array}$ & 1968 & $\begin{array}{l}\text { Ecology \& } \\
\text { epidemiology }\end{array}$ & $101 / 34$ & [113] \\
\hline 4 & The composition and structure of walls of dark fungus spores & 1964 & $\begin{array}{l}\text { Experimental } \\
\text { mycology }\end{array}$ & $87 / 35$ & {$[59]$} \\
\hline 5 & $\begin{array}{l}\text { Preparation and properties of the endotoxins of Aspergillus fumigatus and } \\
\text { Aspergillus flavus }\end{array}$ & 1961 & $\begin{array}{l}\text { Experimental } \\
\text { mycology }\end{array}$ & $77 / 22$ & {$[68]$} \\
\hline 6 & $\begin{array}{l}\text { A survey of tide-washed coastal areas of southern California for fungi } \\
\text { potentially pathogenic to man }\end{array}$ & 1964 & $\begin{array}{l}\text { Ecology \& } \\
\text { epidemiology }\end{array}$ & $65 / 23$ & {$[104]$} \\
\hline 7 & Human pathogenic fungi recovered from Brazilian soil & 1964 & $\begin{array}{l}\text { Ecology \& } \\
\text { epidemiology }\end{array}$ & $64 / 21$ & {$[103]$} \\
\hline 8 & Detection of antibodies by microtitrator techniques & 1967 & $\begin{array}{l}\text { Diagnostic } \\
\text { mycology }\end{array}$ & $62 / 17$ & [11] \\
\hline 9 & Lytic action of lysozyme on Candida albicans & 1970 & $\begin{array}{l}\text { Experimental } \\
\text { mycology }\end{array}$ & $60 / 20$ & {$[28]$} \\
\hline 10 & Biochemical and immunological studies on Aspergillus & 1969 & $\begin{array}{l}\text { Experimental } \\
\text { mycology }\end{array}$ & $58 / 17$ & {$[60]$} \\
\hline 11 & Thermophilous fungi of birds' nests & 1967 & $\begin{array}{l}\text { Ecology \& } \\
\text { epidemiology }\end{array}$ & $57 / 24$ & {$[116]$} \\
\hline 12 & $\begin{array}{l}\text { An evaluation of various environmental factors affecting the propagation of } \\
\text { Cryptococcus neoformans }\end{array}$ & 1968 & $\begin{array}{l}\text { Experimental } \\
\text { mycology }\end{array}$ & $55 / 13$ & {$[61]$} \\
\hline 13 & Systematics of yeast species in the Candida parapsilosis group & 1967 & $\begin{array}{l}\text { Taxonomy \& } \\
\text { classification }\end{array}$ & $52 / 25$ & [143] \\
\hline
\end{tabular}

${ }^{\mathrm{a} G o o g l e ~ S c h o l a r / S c o p u s ~}$

\section{Clinical Mycology}

Clinical mycology articles with high citations were few and far between in the earlier decades of publication of Mycopathologia most likely because as large case series were not compiled or were published in more clinically oriented journals. The first noteworthy contribution appeared in 1976 on a clinical model of paracoccidioidomycosis based upon a detailed analysis of 46 cases of the disease (Table 4) [80]. The relevance of the clinical model was enhanced subsequently by other investigators with detailed descriptions of the immunopathology of paracoccidioidomycosis [81-83]. In the early 1970s, an influential publication described the higher prevalence of pathogenic fungi including known agents of onychomycosis in toenails and toe-webs of diabetic patients [84]. Similarly, Vález and Diaz [85] highlighted the role of saprobic fungi as agents of onychomycosis, and Godoy and colleagues [86] highlighted Fusarium solani and $F$. oxysporum as agents of onychomycosis (Tables 5, 7). Gupta and Cooper [87] had the unique distinction of publishing the highest cited Mycopathologia article to date that described the antifungal therapy of dermatophytosis (Table 7). Uribe et al. [88] characterized the histopathological changes presented at different stages of chromoblastomycosis, a significant tropical disease caused by black molds. A subsequent publication by Silva et al. [89] documented the extent of chromoblastomycosis in Amazon region with a predominance of Fonsecaea pedrosoi (Table 6). Queiroz-Telles and Santos [90] published an expert opinion on the treatment challenges and available options for chromoblastomycosis in resource-poor parts of the world. Finally, a valuable addition to the growing collection 
Table 4 Most cited articles published in Mycopathologia 1971-1980

\begin{tabular}{|c|c|c|c|c|c|}
\hline & Title & Year & Subcategory & Citations $^{\mathrm{a}}$ & References \\
\hline 1 & Serologic aspects on yeast classification & 1974 & $\begin{array}{l}\text { Taxonomy \& } \\
\text { classification }\end{array}$ & $176 / 72$ & [127] \\
\hline 2 & Natural history of the dermatophytes and related fungi & 1974 & $\begin{array}{l}\text { Ecology \& } \\
\text { epidemiology }\end{array}$ & $146 / 59$ & [107] \\
\hline 3 & Paracoccidioides brasiliensis: cell wall structure and virulence & 1977 & $\begin{array}{l}\text { Experimental } \\
\text { mycology }\end{array}$ & $125 / 50$ & [43] \\
\hline 4 & $\begin{array}{l}\text { Chemical and immunological properties of galactomannans obtained from } \\
\text { Histoplasma duboisii, Histoplasma capsulatum, Paracoccidioides } \\
\text { brasiliensis and Blastomyces dermatitidis }\end{array}$ & 1974 & $\begin{array}{l}\text { Experimental } \\
\text { mycology }\end{array}$ & $96 / 26$ & {$[62]$} \\
\hline 5 & $\begin{array}{l}\text { Pathogenesis of Paracoccidioidomycosis: a model based on the study of } 46 \\
\text { patients }\end{array}$ & 1976 & $\begin{array}{l}\text { Clinical } \\
\text { mycology }\end{array}$ & $92 / 33$ & {$[80]$} \\
\hline 6 & A modern system of Fusarium taxonomy & 1974 & $\begin{array}{l}\text { Taxonomy \& } \\
\text { classification }\end{array}$ & $91 / 21$ & [144] \\
\hline 7 & $\begin{array}{l}\text { Prevalence of pathogenic fungi in the toe-webs and toe-nails of diabetic } \\
\text { patients }\end{array}$ & 1979 & $\begin{array}{l}\text { Clinical } \\
\text { mycology }\end{array}$ & $87 / 34$ & [84] \\
\hline 8 & $\begin{array}{l}\text { Activation of the alternative pathway of complement by Malassezia ovalis } \\
\text { (Pityrosporum ovale) }\end{array}$ & 1980 & $\begin{array}{l}\text { Experimental } \\
\text { mycology }\end{array}$ & $80 / 33$ & [44] \\
\hline 9 & $\begin{array}{l}\text { Comparative recoveries of airborne fungus spores by viable and non-viable } \\
\text { modes of volumetric collection }\end{array}$ & 1977 & $\begin{array}{l}\text { Ecology \& } \\
\text { epidemiology }\end{array}$ & $74 / 33$ & [109] \\
\hline 10 & $\begin{array}{l}\text { Comparison by ELISA of serum anti-Candida albicans mannan IgG levels } \\
\text { of a normal population and in diseased patients }\end{array}$ & 1980 & $\begin{array}{l}\text { Diagnostic } \\
\text { mycology }\end{array}$ & $68 / 25$ & [13] \\
\hline 11 & Counterimmunoelectrophoresis as a routine mycoserological procedure & 1975 & $\begin{array}{l}\text { Diagnostic } \\
\text { mycology }\end{array}$ & $50 / 18$ & [12] \\
\hline
\end{tabular}

${ }^{\mathrm{a} G o o g l e ~ S c h o l a r / S c o p u s ~}$

of high-impact publications on chromoblastomycosis came from Lyon et al. [91] who showed clinical evidence of the effectiveness of photodynamic therapy in ten patients (Table 8). Queiroz-Telles' group have continued their productive work on chromoblastomycosis with a recent update in Clinical Microbiology Reviews [92].

A relatively recent overview of candidiasis by Martins and colleagues [93] was well received for its emphasis on predisposition, prevention and control, and the role of alternative treatment approaches (Table 8). A brief report on the etiologic role of $C$. albicans in otitis externa received notable citations given enhanced interests in the multidrug resistance $C$. auris from aural specimens [94, 95]. The reviews of cryptococcosis in Brazil by Rozenbaum et al. [96] and in China by Chen et al. [97] received high citations (Tables 6,8). The authors highlighted the distribution of different Cryptococcus pathogenic species and molecular genotypes among patients with or without underlying immune deficiencies. The disease pattern in these geographically diverse countries with large populations differed from earlier knowledge of the disease reported from North America. Xi et al. [98] provided a comprehensive clinical and mycological profile of penicilliosis due to Talaromyces (Penicillium) marneffei from Guangdong, China, with strong supportive evidence for the natural distribution of the fungus in Southeast China (Table 7). Xi's group expanded their excellent overview of the penicilliosis by classifying it as an important emerging disease in China [99]. Other notable contributions in clinical mycology were the overview of filamentous fungal infections among patients receiving hematopoietic stem cell therapy, appropriate laboratory diagnostic methods for coccidioidomycosis, and clinical efficacy and relevance of isavuconazole, then a new triazole antifungal (Table 7) [100-102].

\section{Ecology and Epidemiology}

The ecology and epidemiology subcategory articles have few common themes: the natural occurrence of pathogenic fungi in the soil, air, and water in diverse 
Table 5 Most cited articles published in Mycopathologia 1981-1990

\begin{tabular}{|c|c|c|c|c|c|}
\hline & Title & Year & Subcategory & Citations $^{\mathrm{a}}$ & References \\
\hline 1 & A characterization of $\mathrm{pH}$-regulated dimorphism in Candida albicans & 1984 & $\begin{array}{l}\text { Experimental } \\
\text { mycology }\end{array}$ & $241 / 97$ & {$[63]$} \\
\hline 2 & $\begin{array}{l}\text { Decreased virulence in stable, acapsular mutants of Cryptococcus } \\
\text { neoformans }\end{array}$ & 1982 & $\begin{array}{l}\text { Experimental } \\
\text { mycology }\end{array}$ & $191 / 68$ & [45] \\
\hline 3 & $\begin{array}{l}\text { Variation in adhesion and cell surface hydrophobicity in Candida albicans } \\
\text { white and opaque phenotypes }\end{array}$ & 1988 & $\begin{array}{l}\text { Experimental } \\
\text { mycology }\end{array}$ & $109 / 40$ & {$[64]$} \\
\hline 4 & $\begin{array}{l}\text { A survey of dermatophytes isolated from human patients in the United States } \\
\text { from } 1979 \text { to } 1981 \text { with chronological listings of worldwide incidence of } \\
\text { five dermatophytes often isolated in the United States }\end{array}$ & 1984 & $\begin{array}{l}\text { Ecology \& } \\
\text { epidemiology }\end{array}$ & $91 / 63$ & {$[108]$} \\
\hline 5 & Strain differentiation of pathogenic yeasts by the killer system & 1984 & $\begin{array}{l}\text { Diagnostic } \\
\text { mycology }\end{array}$ & $83 / 34$ & {$[14]$} \\
\hline 6 & Fungi in bathwater and sludge of bathroom drainpipes & 1987 & $\begin{array}{l}\text { Ecology \& } \\
\text { epidemiology }\end{array}$ & $81 / 45$ & {$[118]$} \\
\hline 7 & Studies on a saprophyte of Exophiala dermatitidis isolated from a humidifier & 1982 & $\begin{array}{l}\text { Experimental } \\
\text { mycology }\end{array}$ & $80 / 35$ & {$[65]$} \\
\hline 8 & $\begin{array}{l}\text { In vivo and in vitro characteristics of six Paracoccidioides brasiliensis } \\
\text { strains }\end{array}$ & 1985 & $\begin{array}{l}\text { Experimental } \\
\text { mycology }\end{array}$ & $79 / 48$ & [46] \\
\hline 9 & $\begin{array}{l}\text { Experimental pulmonary paracoccidioidomycosis in mice: Morphology and } \\
\text { correlation of lesions with humoral and cellular immune response }\end{array}$ & 1982 & $\begin{array}{l}\text { Experimental } \\
\text { mycology }\end{array}$ & $78 / 35$ & [47] \\
\hline 10 & $\begin{array}{l}\text { Analysis of restriction profiles of Mitochondrial DNA from Sporothrix } \\
\text { schenckii and related fungi }\end{array}$ & 1988 & $\begin{array}{l}\text { Diagnostic } \\
\text { mycology }\end{array}$ & $77 / 26$ & [18] \\
\hline 11 & $\begin{array}{l}\text { Virulence of Paracoccidioides brasiliensis: The influence of in vitro passage } \\
\text { and storage }\end{array}$ & 1990 & $\begin{array}{l}\text { Experimental } \\
\text { mycology }\end{array}$ & $77 / 39$ & [48] \\
\hline 12 & Preservation of fungi in water (Castellani): 20 years & 1989 & $\begin{array}{l}\text { Diagnostic } \\
\text { mycology }\end{array}$ & $73 / 35$ & {$[145]$} \\
\hline 13 & Penicillosis marneffei: Serological and exoantigen studies & 1982 & $\begin{array}{l}\text { Diagnostic } \\
\text { mycology }\end{array}$ & $69 / 29$ & {$[15]$} \\
\hline 14 & Effects of iron and desferrioxamine on Rhizopus infection & 1990 & $\begin{array}{l}\text { Experimental } \\
\text { mycology }\end{array}$ & $69 / 28$ & {$[56]$} \\
\hline 15 & $\begin{array}{l}\text { T-cell dysfunction and hyperimmunoglobulinemia } \mathrm{E} \text { in } \\
\text { paracoccidioidomycosis }\end{array}$ & 1982 & $\begin{array}{l}\text { Clinical } \\
\text { mycology }\end{array}$ & $67 / 27$ & {$[81]$} \\
\hline 16 & Onychomycosis due to saprophytic fungi & 1985 & $\begin{array}{l}\text { Clinical } \\
\text { mycology }\end{array}$ & $63 / 34$ & {$[85]$} \\
\hline 17 & Survey of the mycoflora of desert soils in Saudi Arabia & 1982 & $\begin{array}{l}\text { Ecology \& } \\
\text { epidemiology }\end{array}$ & $61 / 25$ & {$[105]$} \\
\hline 18 & Histopathology of chromoblastomycosis & 1989 & $\begin{array}{l}\text { Clinical } \\
\text { mycology }\end{array}$ & $61 / 30$ & {$[88]$} \\
\hline 19 & Keratinophilic fungi isolated from Antarctic soil & 1989 & $\begin{array}{l}\text { Ecology \& } \\
\text { epidemiology }\end{array}$ & $61 / 23$ & [106] \\
\hline 20 & $\begin{array}{l}\text { Circulating immune complexes and in vitro cell reactivity in } \\
\text { paracoccidioidomycosis }\end{array}$ & 1982 & $\begin{array}{l}\text { Clinical } \\
\text { mycology }\end{array}$ & $58 / 63$ & [82] \\
\hline 21 & $\begin{array}{l}\text { Morphogenesis throughout saprobic and parasitic cycles of Coccidioides } \\
\text { immitis }\end{array}$ & 1982 & $\begin{array}{l}\text { Experimental } \\
\text { mycology }\end{array}$ & $57 / 22$ & [66] \\
\hline 22 & $\begin{array}{l}\text { Isolation of Phialophora verrucosa and Fonsecaea pedrosoi from nature in } \\
\text { Japan }\end{array}$ & 1981 & $\begin{array}{l}\text { Ecology \& } \\
\text { epidemiology }\end{array}$ & $56 / 21$ & [146] \\
\hline 23 & $\begin{array}{l}\text { Granuloma formation and killing functions of granuloma in congenitally } \\
\text { athymic nude mice infected with Blastomyces dermatitidis and } \\
\text { Paracoccidioides brasiliensis }\end{array}$ & 1983 & $\begin{array}{l}\text { Experimental } \\
\text { mycology }\end{array}$ & $52 / 25$ & [49] \\
\hline
\end{tabular}

${ }^{\mathrm{a} G o o g l e ~ S c h o l a r / S c o p u s ~}$ 
Table 6 Most cited articles published in Mycopathologia 1991-2000

\begin{tabular}{|c|c|c|c|c|c|}
\hline & Title & Year & Subcategory & Citations $^{\mathrm{a}}$ & References \\
\hline 1 & $\begin{array}{l}\text { Airborne fungal colony-forming units in outdoor and indoor environments in } \\
\text { Yokohama, Japan }\end{array}$ & 1997 & $\begin{array}{l}\text { Ecology \& } \\
\text { epidemiology }\end{array}$ & $165 / 75$ & [110] \\
\hline 2 & $\begin{array}{l}\text { Chromoblastomycosis: a retrospective study of } 325 \text { cases on Amazonic } \\
\text { Region (Brazil) }\end{array}$ & 1998 & $\begin{array}{l}\text { Clinical } \\
\text { mycology }\end{array}$ & $140 / 74$ & [89] \\
\hline 3 & $\begin{array}{l}\text { Differentiation of three biotypes of Malassezia species on human normal } \\
\text { skin. Correspondence with } M \text {. globosa, } M \text {. sympodialis and } M \text {. restricta }\end{array}$ & 1999 & $\begin{array}{l}\text { Diagnostic } \\
\text { mycology }\end{array}$ & $91 / 32$ & [147] \\
\hline 4 & Extracellular proteolytic activity of Cryptococcus neoformans & 1994 & $\begin{array}{l}\text { Experimental } \\
\text { mycology }\end{array}$ & $79 / 34$ & [69] \\
\hline 5 & $\begin{array}{l}\text { The time course of responses to intratracheally instilled toxic Stachybotrys } \\
\text { chartarum spores in rats }\end{array}$ & 2000 & $\begin{array}{l}\text { Experimental } \\
\text { mycology }\end{array}$ & $74 / 29$ & [50] \\
\hline 6 & $\begin{array}{l}\text { Effect of nucleosides and nucleotides and the relationship between cellular } \\
\text { adenosine } 3^{\prime}: 5^{\prime} \text {-cyclic monophosphate (cyclic AMP) and germ tube } \\
\text { formation in Candida albicans }\end{array}$ & 1992 & $\begin{array}{l}\text { Experimental } \\
\text { mycology }\end{array}$ & $70 / 28$ & [67] \\
\hline 7 & $\begin{array}{l}\text { Occurrence of Penicillium marneffei infections among wild bamboo rats in } \\
\text { Thailand }\end{array}$ & 1995 & $\begin{array}{l}\text { Ecology \& } \\
\text { epidemiology }\end{array}$ & $68 / 30$ & [117] \\
\hline 8 & $\begin{array}{l}\text { Microbiological characteristics and susceptibility patterns of strains of } \\
\text { Rhodotorula isolated from clinical samples }\end{array}$ & 1999 & $\begin{array}{l}\text { Diagnostic } \\
\text { mycology }\end{array}$ & $66 / 32$ & [19] \\
\hline 9 & $\begin{array}{l}\text { Prevalence, epidemiology and geographical distribution of Sporothrix } \\
\text { schenckii infections in Gauteng, South Africa }\end{array}$ & 1997 & $\begin{array}{l}\text { Ecology \& } \\
\text { epidemiology }\end{array}$ & $62 / 32$ & [148] \\
\hline 10 & Phospholipase activity in Cryptococcus neoformans & 1996 & $\begin{array}{l}\text { Experimental } \\
\text { mycology }\end{array}$ & $61 / 25$ & [70] \\
\hline 11 & Clinical isolates of yeast produce a gliotoxin-like substance & 1991 & $\begin{array}{l}\text { Experimental } \\
\text { mycology }\end{array}$ & $58 / 16$ & [71] \\
\hline 12 & Cryptococcus neoformans varieties as agents of cryptococcosis in Brazil & 1992 & $\begin{array}{l}\text { Clinical } \\
\text { mycology }\end{array}$ & $58 / 24$ & [96] \\
\hline 13 & The antifungal action of dandruff shampoos & 1999 & $\begin{array}{l}\text { Experimental } \\
\text { mycology }\end{array}$ & $58 / 22$ & [29] \\
\hline 14 & $\begin{array}{l}\text { In vitro activity of a new triazole antifungal agent, Sch 56592, against } \\
\text { clinical isolates of filamentous fungi }\end{array}$ & 1998 & $\begin{array}{l}\text { Experimental } \\
\text { mycology }\end{array}$ & $56 / 26$ & {$[30]$} \\
\hline 15 & $\begin{array}{l}\text { Effects of dietary sugars and saliva and serum on Candida biofilm formation } \\
\text { on acrylic surfaces }\end{array}$ & 1997 & $\begin{array}{l}\text { Experimental } \\
\text { mycology }\end{array}$ & $54 / 20$ & [33] \\
\hline 16 & Evaluation of two vaccines for the treatment of pythiosis insidiosi in horses & 1992 & $\begin{array}{l}\text { Veterinary } \\
\text { mycology }\end{array}$ & $52 / 27$ & [149] \\
\hline 17 & $\begin{array}{l}\text { Mushroom worker's lung: serologic reactions to thermophilic actinomycetes } \\
\text { present in the air of compost tunnels }\end{array}$ & 1993 & $\begin{array}{l}\text { Clinical } \\
\text { mycology }\end{array}$ & $54 / 22$ & [150] \\
\hline 18 & $\begin{array}{l}\text { Hyperthermic treatment of chromomycosis with disposable chemical pocket } \\
\text { warmers }\end{array}$ & 1993 & $\begin{array}{l}\text { Clinical } \\
\text { mycology }\end{array}$ & $52 / 23$ & [151] \\
\hline 19 & $\begin{array}{l}\text { Mitochondrial DNA analysis of Sporothrix schenckii in North and South } \\
\text { America }\end{array}$ & 1998 & $\begin{array}{l}\text { Diagnostic } \\
\text { mycology }\end{array}$ & $50 / 22$ & [17] \\
\hline
\end{tabular}

${ }^{\mathrm{a} G o o g l e ~ S c h o l a r / S c o p u s ~}$

habitats; the association of fungal pathogens with birds and other animals in nature; and the epidemiology of dermatophytosis (Tables 2, 3, 4, 5). The evolving appreciation for the extensive occurrence of pathogenic fungi in soil was reinforced with welldocumented reports from California, Brazil, Saudi
Arabia, and Antarctica [103-106]. Ajello's natural history of dermatophytes and related fungi, a citation classic, is a comprehensive description of the natural habitats of Epidermophyton, Microsporum, and Trichophyton since their earliest recognition in 1847 [107]. Sinski and Flouras [108] provided a global 
Table 7 Most cited articles published in Mycopathologia 2001-2010

\begin{tabular}{|c|c|c|c|c|c|}
\hline & Title & Year & Subcategory & Citations $^{\mathrm{a}}$ & References \\
\hline 1 & Update in antifungal therapy of dermatophytosis & 2008 & $\begin{array}{l}\text { Clinical } \\
\text { mycology }\end{array}$ & $281 / 120$ & [87] \\
\hline 2 & $\begin{array}{l}\text { In vitro antifungal activities of voriconazole and reference agents as } \\
\text { determined by NCCLS methods: Review of the literature }\end{array}$ & 2001 & $\begin{array}{l}\text { Diagnostic } \\
\text { mycology }\end{array}$ & $278 / 133$ & {$[20]$} \\
\hline 3 & The new species concept in dermatophytes-a polyphasic approach & 2008 & $\begin{array}{l}\text { Taxonomy \& } \\
\text { classification }\end{array}$ & $211 / 115$ & {$[128]$} \\
\hline 4 & $\begin{array}{l}\text { The inhibition of Candida albicans by selected essential oils and their major } \\
\text { components }\end{array}$ & 2005 & $\begin{array}{l}\text { Experimental } \\
\text { mycology }\end{array}$ & $191 / 79$ & {$[31]$} \\
\hline 5 & Antifungal resistance mechanisms in dermatophytes & 2008 & $\begin{array}{l}\text { Clinical } \\
\text { mycology }\end{array}$ & $177 / 71$ & {$[152]$} \\
\hline 6 & $\begin{array}{l}\text { Correlation between gliotoxin production and virulence of Aspergillus } \\
\text { fumigatus in Galleria mellonella }\end{array}$ & 2004 & $\begin{array}{l}\text { Experimental } \\
\text { mycology }\end{array}$ & $145 / 85$ & {$[72]$} \\
\hline 7 & $\begin{array}{l}\text { Presence of extracellular DNA in the Candida albicans biofilm matrix and } \\
\text { its contribution to biofilms }\end{array}$ & 2010 & $\begin{array}{l}\text { Experimental } \\
\text { mycology }\end{array}$ & $145 / 95$ & {$[34]$} \\
\hline 8 & An overview of the immunopathology of human paracoccidioidomycosis & 2008 & $\begin{array}{l}\text { Clinical } \\
\text { mycology }\end{array}$ & $130 / 76$ & [83] \\
\hline 9 & In vitro activity of eugenol against Candida albicans biofilms & 2007 & $\begin{array}{l}\text { Experimental } \\
\text { mycology }\end{array}$ & $121 / 51$ & {$[35]$} \\
\hline 10 & $\begin{array}{l}\text { Isolation of Malassezia globosa and } M \text {. sympodialis from patients with } \\
\text { pityriasis versicolor in Spain }\end{array}$ & 2002 & $\begin{array}{l}\text { Diagnostic } \\
\text { mycology }\end{array}$ & $110 / 40$ & {$[153]$} \\
\hline 11 & $\begin{array}{l}\text { Isavuconazole: A Comprehensive Review of Spectrum of Activity of a New } \\
\text { Triazole }\end{array}$ & 2010 & $\begin{array}{l}\text { Clinical } \\
\text { mycology }\end{array}$ & $109 / 61$ & {$[102]$} \\
\hline 12 & $\begin{array}{l}\text { Serologic testing for symptomatic coccidioidomycosis in immunocompetent } \\
\text { and immunosuppressed hosts }\end{array}$ & 2006 & $\begin{array}{l}\text { Clinical } \\
\text { mycology }\end{array}$ & $100 / 64$ & {$[101]$} \\
\hline 13 & Biodiversity and concentration of airborne fungi in a hospital environment & 2001 & $\begin{array}{l}\text { Ecology \& } \\
\text { epidemiology }\end{array}$ & $95 / 32$ & [111] \\
\hline 14 & $\begin{array}{l}\text { Occurrence and population size of Malassezia spp. in the external ear canal } \\
\text { of dogs and cats both healthy and with otitis }\end{array}$ & 2005 & $\begin{array}{l}\text { Veterinary } \\
\text { mycology }\end{array}$ & $92 / 33$ & [132] \\
\hline 15 & $\begin{array}{l}\text { Molecular analysis of Malassezia microflora from patients with pityriasis } \\
\text { versicolor }\end{array}$ & 2006 & $\begin{array}{l}\text { Diagnostic } \\
\text { mycology }\end{array}$ & $92 / 51$ & {$[16]$} \\
\hline 16 & $\begin{array}{l}\text { The use of new probes and stains for improved assessment of cell viability } \\
\text { and extracellular polymeric substances in Candida albicans biofilms }\end{array}$ & 2005 & $\begin{array}{l}\text { Experimental } \\
\text { mycology }\end{array}$ & $87 / 49$ & {$[36]$} \\
\hline 17 & Occurrence of yeasts in cloacae of migratory birds & 2006 & $\begin{array}{l}\text { Veterinary } \\
\text { mycology }\end{array}$ & $86 / 53$ & {$[137]$} \\
\hline 18 & Serology of paracoccidioidomycosis & 2008 & $\begin{array}{l}\text { Diagnostic } \\
\text { mycology }\end{array}$ & $86 / 35$ & {$[154]$} \\
\hline 19 & $\begin{array}{l}\text { Sporothrix schenckii isolated from domestic cats with and without } \\
\text { sporotrichosis in Rio de Janeiro, Brazil }\end{array}$ & 2002 & $\begin{array}{l}\text { Veterinary } \\
\text { mycology }\end{array}$ & $85 / 45$ & {$[136]$} \\
\hline 20 & $\begin{array}{l}\text { Invasive filamentous fungal infections in allogeneic hematopoietic stem cell } \\
\text { transplant recipients after recovery from neutropenia: Clinical, radiologic, } \\
\text { and pathologic characteristics }\end{array}$ & 2005 & $\begin{array}{l}\text { Clinical } \\
\text { mycology }\end{array}$ & $84 / 40$ & {$[100]$} \\
\hline 21 & $\begin{array}{l}\text { Acid proteinase, phospholipase, and biofilm production of Candida species } \\
\text { isolated from blood cultures }\end{array}$ & 2007 & $\begin{array}{l}\text { Experimental } \\
\text { mycology }\end{array}$ & $82 / 43$ & {$[155]$} \\
\hline 22 & Isolation and toxigenicity of Aspergillus fumigatus from moldy silage & 2003 & $\begin{array}{l}\text { Ecology \& } \\
\text { epidemiology }\end{array}$ & $81 / 44$ & [119] \\
\hline 23 & $\begin{array}{l}\text { Cryptococcus neoformans and Cryptococcus gattii isolated from the excreta } \\
\text { of Psittaciformes in a Southern Brazilian zoological garden }\end{array}$ & 2006 & $\begin{array}{l}\text { Veterinary } \\
\text { mycology }\end{array}$ & $81 / 35$ & {$[138]$} \\
\hline 24 & $\begin{array}{l}\text { High rate of Microsporum canis feline and canine dermatophytoses in } \\
\text { Northeast Brazil: epidemiological and diagnostic features }\end{array}$ & 2003 & $\begin{array}{l}\text { Veterinary } \\
\text { mycology }\end{array}$ & $76 / 21$ & [133] \\
\hline
\end{tabular}


Table 7 continued

\begin{tabular}{|c|c|c|c|c|c|}
\hline & Title & Year & Subcategory & Citations $^{\mathrm{a}}$ & References \\
\hline 25 & $\begin{array}{l}\text { Inhibition on Candida albicans biofilm formation using divalent cation } \\
\text { chelators (EDTA) }\end{array}$ & 2007 & $\begin{array}{l}\text { Experimental } \\
\text { mycology }\end{array}$ & $75 / 34$ & [37] \\
\hline 26 & $\begin{array}{l}\text { Dermatophytes isolated from symptomatic dogs and cats in Tuscany, Italy } \\
\text { during a } 15 \text {-year-period }\end{array}$ & 2003 & $\begin{array}{l}\text { Veterinary } \\
\text { mycology }\end{array}$ & $74 / 33$ & [134] \\
\hline 27 & Fifteen cases of penicilliosis in Guangdong, China & 2004 & $\begin{array}{l}\text { Clinical } \\
\text { mycology }\end{array}$ & $74 / 31$ & [98] \\
\hline 28 & $\begin{array}{l}\text { Influence of Th1/Th2 cytokines and nitric oxide in murine systemic infection } \\
\text { induced by Sporothrix schenckii }\end{array}$ & 2006 & $\begin{array}{l}\text { Experimental } \\
\text { mycology }\end{array}$ & $71 / 38$ & [51] \\
\hline 29 & $\begin{array}{l}\text { Effect of pre-incubation temperature on susceptibility of Galleria mellonella } \\
\text { larvae to infection by Candida albicans }\end{array}$ & 2008 & $\begin{array}{l}\text { Experimental } \\
\text { mycology }\end{array}$ & $71 / 46$ & [52] \\
\hline 30 & $\begin{array}{l}\text { Phospholipase and proteinase activities of clinical isolates of Candida from } \\
\text { immunocompromised patients }\end{array}$ & 2006 & $\begin{array}{l}\text { Experimental } \\
\text { mycology }\end{array}$ & $70 / 42$ & [73] \\
\hline 31 & $\begin{array}{l}\text { Examination of potential virulence factors of Candida tropicalis clinical } \\
\text { isolates from hospitalized patients }\end{array}$ & 2010 & $\begin{array}{l}\text { Experimental } \\
\text { mycology }\end{array}$ & $70 / 42$ & {$[158]$} \\
\hline 32 & $\begin{array}{l}\text { In Vitro investigation of antifungal activity of allicin alone and in } \\
\text { combination with azoles against Candida Species }\end{array}$ & 2010 & $\begin{array}{l}\text { Experimental } \\
\text { mycology }\end{array}$ & $66 / 20$ & [32] \\
\hline 33 & $\begin{array}{l}\text { Occurrence of Malassezia species in healthy and dermatologically diseased } \\
\text { dogs }\end{array}$ & 2004 & $\begin{array}{l}\text { Veterinary } \\
\text { mycology }\end{array}$ & $65 / 23$ & {$[135]$} \\
\hline 34 & $\begin{array}{l}\text { Melanization decreases the susceptibility of Cryptococcus neoformans to } \\
\text { enzymatic degradation }\end{array}$ & 2001 & $\begin{array}{l}\text { Experimental } \\
\text { mycology }\end{array}$ & $64 / 32$ & [74] \\
\hline 35 & $\begin{array}{l}\text { Susceptibility of larvae of Galleria mellonella to infection by Aspergillus } \\
\text { fumigatus is dependent upon stage of conidial germination }\end{array}$ & 2006 & $\begin{array}{l}\text { Experimental } \\
\text { mycology }\end{array}$ & $61 / 44$ & [54] \\
\hline 36 & $\begin{array}{l}\text { Onychomycosis caused by Fusarium solani and Fusarium oxysporum in São } \\
\text { Paulo, Brazil }\end{array}$ & 2004 & $\begin{array}{l}\text { Clinical } \\
\text { mycology }\end{array}$ & $63 / 29$ & [86] \\
\hline 37 & $\begin{array}{l}\text { Metabolite profiles of Stachybotrys isolates from water-damaged buildings } \\
\text { and their induction of inflammatory mediators and cytotoxicity in } \\
\text { macrophages }\end{array}$ & 2002 & $\begin{array}{l}\text { Ecology \& } \\
\text { epidemiology }\end{array}$ & $61 / 35$ & [112] \\
\hline 38 & Epidemiology and molecular typing of Candida isolates from burn patients & 2004 & $\begin{array}{l}\text { Ecology \& } \\
\text { epidemiology }\end{array}$ & $61 / 26$ & [156] \\
\hline 39 & $\begin{array}{l}\text { Design of a simple model of Candida albicans biofilms formed under } \\
\text { conditions of flow: development, architecture, and drug resistance }\end{array}$ & 2009 & $\begin{array}{l}\text { Experimental } \\
\text { mycology }\end{array}$ & $61 / 36$ & [38] \\
\hline 40 & $\begin{array}{l}\text { Ecology of dermatophytes and other keratinophilic fungi in swimming pools } \\
\text { and polluted and unpolluted streams }\end{array}$ & 2003 & $\begin{array}{l}\text { Ecology \& } \\
\text { epidemiology }\end{array}$ & $58 / 22$ & {$[157]$} \\
\hline 41 & Etiological Significance of Candida albicans in Otitis Externa & 2003 & $\begin{array}{l}\text { Clinical } \\
\text { mycology }\end{array}$ & $58 / 15$ & [94] \\
\hline 42 & Animal models of allergic bronchopulmonary aspergillosis & 2002 & $\begin{array}{l}\text { Experimental } \\
\text { mycology }\end{array}$ & $57 / 19$ & [55] \\
\hline
\end{tabular}

${ }^{\mathrm{a}}$ Google Scholar/Scopus

picture of the distribution of dermatophytic fungi by comparing their occurrence in the US patients vis-àvis clinical reports from other parts of the world. The aerial prevalence of fungal pathogens over cities was reported with sophisticated samplers, and the role of aerial microbiota inside the hospitals and damp buildings was correlated with the occurrence of fungal diseases [109-112]. Littman and Borok [113] brought scientific rigor to the known association of pigeons with Cryptococcus neoformans by carefully delineating the heat tolerance of the pathogen, its survival in the pigeon body and excreta, and the possible carrier role that pigeons play in the urban environments. Over 40 years later, another notable contribution on cryptococcosis was published and concerned the unique ecological niche of Cryptococcus gattii on trees found on the Vancouver Island, British Columbia, Canada (Table 8) [114]. Additional bird associations were 
Table 8 Most cited articles published in Mycopathologia 2011-2018

\begin{tabular}{|c|c|c|c|c|c|}
\hline & Title & Year & Subcategory & Citations $^{\mathrm{a}}$ & References \\
\hline 1 & Penicillium marneffei infection: an emerging disease in mainland China & 2013 & $\begin{array}{l}\text { Clinical } \\
\text { mycology }\end{array}$ & $98 / 57$ & [99] \\
\hline 2 & $\begin{array}{l}\text { Candidiasis: predisposing factors, prevention, diagnosis and alternative } \\
\text { treatment }\end{array}$ & 2014 & $\begin{array}{l}\text { Clinical } \\
\text { mycology }\end{array}$ & $88 / 48$ & [93] \\
\hline 3 & $\begin{array}{l}\text { Isavuconazole and nine comparator antifungal susceptibility profiles for } \\
\text { common and uncommon Candida Species collected in 2012: application } \\
\text { of new CLSI clinical breakpoints and epidemiological cutoff values }\end{array}$ & 2014 & $\begin{array}{l}\text { Diagnostic } \\
\text { mycology }\end{array}$ & $88 / 16$ & {$[21]$} \\
\hline 4 & Toward a novel multilocus phylogenetic taxonomy for the dermatophytes & 2017 & $\begin{array}{l}\text { Taxonomy \& } \\
\text { classification }\end{array}$ & $60 / 43$ & [129] \\
\hline 5 & $\begin{array}{l}\text { Isolation and screening of black fungi as degraders of volatile aromatic } \\
\text { hydrocarbons }\end{array}$ & 2013 & $\begin{array}{l}\text { Experimental } \\
\text { mycology }\end{array}$ & $58 / 37$ & [75] \\
\hline 6 & A Decade of Experience: Cryptococcus gattii in British Columbia & 2012 & $\begin{array}{l}\text { Ecology \& } \\
\text { epidemiology }\end{array}$ & $54 / 32$ & [114] \\
\hline 7 & $\begin{array}{l}\text { Cryptococcosis in China (1985-2010): review of cases from Chinese } \\
\text { database }\end{array}$ & 2012 & $\begin{array}{l}\text { Clinical } \\
\text { mycology }\end{array}$ & $54 / 27$ & [97] \\
\hline 8 & Aspergillus cell wall and biofilm & 2014 & $\begin{array}{l}\text { Experimental } \\
\text { mycology }\end{array}$ & $54 / 38$ & [39] \\
\hline 9 & Challenges in the therapy of chromoblastomycosis & 2013 & $\begin{array}{l}\text { Clinical } \\
\text { mycology }\end{array}$ & $53 / 25$ & {$[90]$} \\
\hline 10 & Photodynamic antifungal therapy against chromoblastomycosis & 2011 & $\begin{array}{l}\text { Clinical } \\
\text { mycology }\end{array}$ & $52 / 33$ & [91] \\
\hline 11 & $\begin{array}{l}\text { Significance of molecular identification and antifungal susceptibility of } \\
\text { clinically significant yeasts and moulds in a global antifungal surveillance } \\
\text { programme }\end{array}$ & 2012 & $\begin{array}{l}\text { Diagnostic } \\
\text { mycology }\end{array}$ & $51 / 30$ & {$[22]$} \\
\hline
\end{tabular}

${ }^{\mathrm{a}}$ Google Scholar/Scopus

reported for Histoplasma capsulatum from Venezuela and thermophilic fungi with the passerine bird species in Britain $[115,116]$. Among other notable publications in ecology and epidemiology were Talaromyces (Penicillium) marneffei isolated from bamboo rats in Thailand, black yeasts in public bathwater from Japan, and Aspergillus fumigatus in moldy silage on the Azores Islands (Tables 6, 7) [117-119].

\section{Taxonomy and Classification}

Taxonomy and classification especially related to yeasts dominated the initial volumes of Mycopathologia [120-123], and there was an appeal to unify taxonomy, a theme familiar to many of us even today (Table 1) [124, 125]. However, the high-impact contributions to taxonomy and classification in the coming decades were not that many except for the two remarkable contributions on the black yeasts and the serological approaches to yeast classification based upon cell surface antigens (Table 3) [126, 127]. This subcategory has undergone a sort of rejuvenation in Mycopathologia with two articles in the last decade by Profs. de Hoog, Gräser and their colleagues on the reappraisal of taxonomy and species concept in dermatophytes (Tables 7, 8) [128, 129]. The very high citations and downloads of the two articles suggested that high-quality communications on the taxonomy and classification of medically important fungi remained relevant as this area is transformed with the applications of genome sequencing [130].

\section{Veterinary Mycology}

Veterinary mycology-associated reports first appeared in the inaugural issue of Mycopathologia and concerned a case of simian dermatophytosis (Table 1) [131]. This subcategory remained underrepresented until recently. However, the last decade marked the publication of many important descriptions of dermatophytosis, Malassezia and Sporothrix carriage in 
dogs and cats, respectively (Table 7) [132-136]. There were also notable reports on birds as the carriers of yeasts, especially Cryptococcus species [137, 138]. It is clear that veterinary mycology will be crucial in the coming years because of the emerging consensus on One Health approaches for the welfare of the animal and human health [139].

\section{Concluding Remarks}

As we conclude this commemorative article, it is pertinent to ask whether Mycopathologia has met its original mission, if the journal is still providing valuable services to the scientists and physicians interested in pathogenic fungi, and finally, what changes will come as Mycopathologia moves toward its hundredth anniversary in 2038? The answer is an emphatic yes! For the first question with an archive of nearly 6885 articles online and in print (Fig. 2), and each issue continuing the tradition of publishing a mix of articles on pathogenic fungi and fungal diseases. The answer to the second question is complicated as there are many more journals and options for sharing new developments on pathogenic fungi. Thus, Mycopathologia has to seek and share interesting articles with other journals. This is easier to implement, as the investigations of pathogenic fungi have grown manifold with a significant upsurge from the authors in Africa, Asia, and South America (Fig. 3). They are also well represented in the Mycopathologia Editorial Board with more than half of the editors coming from the areas outside of Europe and North America as mentioned earlier. Further answers to questions two and three are tied to the technical and business strengths of our publisher Springer Nature. The publisher is at the forefront of technological changes and business evolution, and indeed, Mycopathologia would be a beneficiary from being part of this progressive company. In recent years, the journal has devoted one-third of its pages annually to the special issues, which bring together recognized experts on a selected topic, and this feature will be further enhanced along with a new feature Mycopathologia Images. We anticipate that emerging and re-emerging fungal pathogens will continue to cause significant health burden in the coming decades [140]. It is, therefore, vital that scientists and physicians continue to collaborate by learning each other's language for the study of fungal diseases, and Mycopathologia will strive to be their partner in this endeavor to its 100th anniversary in 2038 and beyond.

\section{References}

1. DiSalvo AF, Plasterk KJ, Caretta G, Cooke WB, Rippon JW. History of Mycopathologia. Mycopathologia. 1995;131(3):131-47. https://doi.org/10.1007/bf01102893.

2. Blackwell M. The fungi: 1, 2, 3 .. 5.1 million species? Am J Bot. 2011;98(3):426-38. https://doi.org/10.3732/ajb. 1000298.

3. Edsall JT. The Journal of Biological Chemistry after seventy-five years. J Biol Chem. 1980;255(19):8939-51.

4. Hopp WJ. Fifty years of management science. Manag Sci. 2004;50(1):1-7.

5. Leydesdorff L, Bornmann L, Comins JA, Milojević S. Citations: indicators of quality? The impact fallacy. Front Res Metr Anal. 2016;1:1. https://doi.org/10.3389/frma. 2016.00001.

6. Martín-Martín A, Orduna-Malea E, Thelwall M, Delgado López-Cózar E. Google Scholar, Web of Science, and Scopus: a systematic comparison of citations in 252 subject categories. J Informetr. 2018;12(4):1160-77. https:// doi.org/10.1016/j.joi.2018.09.002.

7. Moore M. Cultivation of Malassezia furfur, etiological agent of pityriasis (tinea) versicolor. Mycopathologia. 1938;1(1):53-61. https://doi.org/10.1007/bf00440371.

8. Benedek T. Are fermentation tests and biochemical characteristics reliable in the differentiation of monilias? Mycopathologia. 1943;3(3):346-53. https://doi.org/10. 1007/bf00446037.

9. Ajello L, Georg LK. In vitro hair cultures for differentiating between atypical isolates of Trichophyton mentagrophytes and Trichophyton rubrum. Mycopathol Mycol Appl. 1957;8(1):3-17. https://doi.org/10.1007/ bf02053114.

10. Tsuchiya T, Fukazawa Y, Kawakita S. A method for the rapid identification of the genus Candida. Mycopathol Mycol Appl. 1959;10(3):191-206. https://doi.org/10. 1007/bf02053014.

11. Witlin B. Detection of antibodies by microtitrator techniques. Mycopathol Mycol Appl. 1967;33(3):241-57. https://doi.org/10.1007/bf02088916.

12. Mackenzie DWR, Philpot CM. Counterimmunoelectrophoresis as a routine mycoserological procedure. Mycopathologia. 1975;57(1):1-7. https://doi.org/10.1007/ bf00431169.

13. Lehmann PF, Reiss E. Comparison by Elisa of serum antiCandida albicans mannan IgG levels of a normal population and in diseased patients. Mycopathologia. 1980;70(2):89-93. https://doi.org/10.1007/bf00443073.

14. Morace G, Archibusacci C, Sestito M, Polonelli L. Strain differentiation of pathogenic yeasts by the killer system. Mycopathologia. 1984;84(2):81-5. https://doi.org/10. 1007/bf00436517. 
15. Sekhon AS, Li JSK, Garg AK. Penicillosis marneffei: serological and exoantigen studies. Mycopathologia. 1982;77(1):51-7. https://doi.org/10.1007/bf00588658.

16. Morishita N, Sei Y, Sugita T. Molecular analysis of Malassezia microflora from patients with pityriasis versicolor. Mycopathologia. 2006;161(2):61-5. https://doi.org/ 10.1007/s11046-005-0149-4.

17. Ishizaki H, Kawasaki M, Aoki M, Matsumoto T, Padhye AA, Mendoza M, et al. Mitochondrial DNA analysis of Sporothrix schenckii in North and South America. Mycopathologia. 1998;142(3):115-8. https://doi.org/10.1023/a: 1006952702947.

18. Suzuki K, Kawasaki M, Ishizaki H. Analysis of restriction profiles of mitochondrial DNA from Sporothrix schenckii and related fungi. Mycopathologia. 1988;103(3):147-51. https://doi.org/10.1007/bf00436813.

19. Galán-Sánchez F, García-Martos P, Rodríguez-Ramos C, Marín-Casanova P, Mira-Gutiérrez J. Microbiological characteristics and susceptibility patterns of strains of Rhodotorula isolated from clinical samples. Mycopathologia. 1999;145(3):109-12. https://doi.org/10.1023/ a: 1007059005753 .

20. Espinel-Ingroff A, Boyle K, Sheehan DJ. In vitro antifungal activities of voriconazole and reference agents as determined by NCCLS methods: review of the literature. Mycopathologia. 2001;150(3):101-15. https://doi.org/10. 1023/a:1010954803886.

21. Castanheira M, Messer SA, Rhomberg PR, Dietrich RR, Jones RN, Pfaller MA. Isavuconazole and nine comparator antifungal susceptibility profiles for common and uncommon Candida species collected in 2012: application of new CLSI clinical breakpoints and epidemiological cutoff values. Mycopathologia. 2014;178(1):1-9. https:// doi.org/10.1007/s11046-014-9772-2.

22. Pfaller MA, Woosley LN, Messer SA, Jones RN, Castanheira M. Significance of molecular identification and antifungal susceptibility of clinically significant yeasts and moulds in a global antifungal surveillance programme. Mycopathologia. 2012;174(4):259-71. https://doi.org/10. 1007/s11046-012-9551-x.

23. Ivy MI, Thoendel MJ, Jeraldo PR, Greenwood-Quaintance KE, Hanssen AD, Abdel MP, et al. Direct detection and identification of prosthetic joint infection pathogens in synovial fluid by metagenomic shotgun sequencing. J Clin Microbiol. 2018;56(9):00402-18. https://doi.org/10.1128/ jcm.00402-18.

24. Tiwari S, Thakur R, Goel G, Shankar J. Nano-LC-Q-TOF analysis of proteome revealed germination of Aspergillus flavus conidia is accompanied by MAPK signalling and cell wall modulation. Mycopathologia. 2016;181(11):769-86. https://doi.org/10.1007/s11046-016-0056-x.

25. Shankar J, Cerqueira GC, Wortman JR, Clemons KV, Stevens DA. RNA-Seq profile reveals Th-1 and Th-17-type of immune responses in mice infected systemically with Aspergillus fumigatus. Mycopathologia. 2018;183(4): 645-58. https://doi.org/10.1007/s11046-018-0254-9.

26. Magni G. Biological significance of the pseudomycelium in asporogenous yeasts. Mycopathologia. 1943;4(1):207-14. https://doi.org/10.1007/bf01237143.

27. Fedors P. Inhibition of Histoplasma capsulatum and Blastomyces dermatitidis by Pseudomonas aeruginosa in vitro. Mycopathologia. 1959;11(1):128-34. https://doi. org/10.1007/bf02051613.

28. Kamaya T. Lytic action of lysozyme on Candida albicans. Mycopathol Mycol Appl. 1970;42(3):197-207. https://doi. org/10.1007/bf02051947.

29. Bulmer AC, Bulmer GS. The antifungal action of dandruff shampoos. Mycopathologia. 1999;147(2):63-5. https:// doi.org/10.1023/a:1007132830164.

30. Marco F, Pfaller MA, Messer SA, Jones RN. In vitro activity of a new triazole antifungal agent, Sch 56592, against clinical isolates of filamentous fungi. Mycopathologia. 1998;141(2):73-7. https://doi.org/10.1023/a: 1006970503053.

31. Tampieri MP, Galuppi R, Macchioni F, Carelle MS, Falcioni L, Cioni PL, et al. The inhibition of Candida albicans by selected essential oils and their major components. Mycopathologia. 2005;159(3):339-45. https://doi.org/10. 1007/s11046-003-4790-5.

32. Khodavandi A, Alizadeh F, Aala F, Sekawi Z, Chong PP. In vitro investigation of antifungal activity of allicin alone and in combination with azoles against Candida species. Mycopathologia. 2010;169(4):287-95. https://doi.org/10. 1007/s11046-009-9251-3.

33. Nikawa H, Nishimura H, Hamada T, Kumagai H, Samaranayake LP. Effects of dietary sugars and saliva and serum on Candida biofilm formation on acrylic surfaces. Mycopathologia. 1997;139(2):87-91. https://doi.org/10. 1023/a:1006851418963.

34. Martins M, Uppuluri P, Thomas DP, Cleary IA, Henriques M, Lopez-Ribot JL, et al. Presence of extracellular DNA in the Candida albicans biofilm matrix and its contribution to biofilms. Mycopathologia. 2010;169(5):323-31. https:// doi.org/10.1007/s11046-009-9264-y.

35. He M, Du M, Fan M, Bian Z. In vitro activity of eugenol against Candida albicans biofilms. Mycopathologia. 2007;163(3):137-43. https://doi.org/10.1007/s11046-0070097-2.

36. Jin Y, Zhang T, Samaranayake YH, Fang HHP, Yip HK, Samaranayake LP. The use of new probes and stains for improved assessment of cell viability and extracellular polymeric substances in Candida albicans biofilms. Mycopathologia. 2005;159(3):353-60. https://doi.org/10. 1007/s11046-004-6987-7.

37. Ramage G, Wickes BL, López-Ribot JL. Inhibition on Candida albicans biofilm formation using divalent cation chelators (EDTA). Mycopathologia. 2007;164(6):301-6. https://doi.org/10.1007/s11046-007-9068-x.

38. Uppuluri P, Chaturvedi AK, Lopez-Ribot JL. Design of a simple model of Candida albicans biofilms formed under conditions of flow: development, architecture, and drug resistance. Mycopathologia. 2009;168(3):101-9. https:// doi.org/10.1007/s11046-009-9205-9.

39. Beauvais A, Fontaine T, Aimanianda V, Latgé J-P. Aspergillus cell wall and biofilm. Mycopathologia. 2014;178(5):371-7. https://doi.org/10.1007/s11046-0149766-0.

40. Schwarz J, Baum GL, Wang CJK, Bingham EL, Rubel H. Successful infection of pigeons and chickens with Histoplasma capsulatum. Mycopathol Mycol Appl. 1957;8(3):189-93. https://doi.org/10.1007/bf02052831. 
41. Hurd RC, Drake CH. Candida albicans infections in actively and passively immunized animals. Mycopathol Mycol Appl. 1953;6(4):290-7. https://doi.org/10.1007/ bf02056710.

42. Friedman L, Smith CE. The comparison of four strains of Coccidioides immitis with diverse histories. Mycopathol Mycol Appl. 1957;8(1):47-53. https://doi.org/10.1007/ bf02053117.

43. San-Blas G, San-Blas F. Paracoccidioides brasiliensis: cell wall structure and virulence. Mycopathologia. 1977;62(2):77-86. https://doi.org/10.1007/bf01259396.

44. Belew PW, Rosenberg EW, Jennings BR. Activation of the alternative pathway of complement by Malassezia ovalis (Pityrosporum ovale). Mycopathologia. 1980;70(3): 187-91. https://doi.org/10.1007/bf00443030.

45. Fromtling RA, Shadomy HJ, Jacobson ES. Decreased virulence in stable, acapsular mutants of Cryptococcus neoformans. Mycopathologia. 1982;79(1):23-9. https:// doi.org/10.1007/bf00636177.

46. Kashino SS, Calich VLG, Burger E, Singer-Vermes LM. In vivo and in vitro characteristics of six Paracoccidioides brasiliensis strains. Mycopathologia. 1985;92(3):173-8. https://doi.org/10.1007/bf00437630.

47. Defaveri J, Rezkallah-Iwasso MT, de Franco MF. Experimental pulmonary paracoccidioidomycosis in mice: morphology and correlation of lesions with humoral and cellular immune response. Mycopathologia. 1982;77(1):3-11. https://doi.org/10.1007/bf00588649.

48. Brummer E, Restrepo A, Hanson LH, Stevens DA. Virulence of Paracoccidioides brasiliensis: the influence of in vitro passage and storage. Mycopathologia. 1990;109(1):13-7. https://doi.org/10.1007/bf00437001.

49. Miyaji M, Nishimura K. Granuloma formation and killing functions of granuloma in congenitally athymic nude mice infected with Blastomyces dermatitidis and Paracoccidioides brasiliensis. Mycopathologia. 1983;82(3):129-41. https://doi.org/10.1007/bf00439218.

50. Rao CY, Burge HA, Brain JD. The time course of responses to intratracheally instilled toxic Stachybotrys chartarum spores in rats. Mycopathologia. 2000;149(1):27-34. https:// doi.org/10.1023/a:1007239017018.

51. Maia DCG, Sassá MF, Placeres MCP, Carlos IZ. Influence of Th1/Th2 cytokines and nitric oxide in murine systemic infection induced by Sporothrix schenckii. Mycopathologia. 2006;161(1):11-9. https://doi.org/10.1007/s11046005-0142-y.

52. Mowlds P, Kavanagh K. Effect of pre-incubation temperature on susceptibility of Galleria mellonella larvae to infection by Candida albicans. Mycopathologia. 2008;165(1):5-12. https://doi.org/10.1007/s11046-0079069-9.

53. Negri M, Martins M, Henriques M, Svidzinski TIE, Azeredo J, Oliveira R. Examination of potential virulence factors of Candida tropicalis clinical isolates from hospitalized patients. Mycopathologia. 2010;169(3):175-82. https://doi.org/10.1007/s11046-009-9246-0.

54. Renwick J, Daly P, Reeves EP, Kavanagh K. Susceptibility of larvae of Galleria mellonella to infection by Aspergillus fumigatus is dependent upon stage of conidial germination. Mycopathologia. 2006;161(6):377-84. https://doi.org/10. 1007/s11046-006-0021-1.
55. Kurup VP, Grunig G. Animal models of allergic bronchopulmonary aspergillosis. Mycopathologia. 2002;153(4): 165-77. https://doi.org/10.1023/a:1014963600314.

56. Abe F, Inaba H, Katoh T, Hotchi M. Effects of iron and desferrioxamine on Rhizopus infection. Mycopathologia. 1990;110(2):87-91. https://doi.org/10.1007/bf00446996.

57. Scherr GH. Studies of the dimorphism mechanism in Saccharomyces cerevisiae. Mycopathol Mycol Appl. 1952;6(3):182-230. https://doi.org/10.1007/bf02081435.

58. Tremaine JH, Miller JJ. Effect of yeast extract, peptone, and certain nitrogen compounds on sporulation of Saccharomyces cerevisiae. Mycopathol Mycol Appl. 1956;7(3):241-50. https://doi.org/10.1007/bf02249074.

59. Durrell LW. The composition and structure of walls of dark fungus spores. Mycopathol Mycol Appl. 1964;23(4):339-45. https://doi.org/10.1007/bf02049005.

60. Azuma I, Kimura H, Hirao F, Tsubura E, Yamamura Y. Biochemical and immunological studies on Aspergillus. Mycopathol Mycol Appl. 1969;37(3):289-303. https://doi. org/10.1007/bf02051363.

61. Ishaq CM, Bulmer GS, Felton FG. An evaluation of various environmental factors affecting the propagation of Cryptococcus neoformans. Mycopathol Mycol Appl. 1968;35(2):81-90. https://doi.org/10.1007/bf02049570.

62. Azuma I, Kanetsuna F, Tanaka Y, Yamamura Y, Carbonell LM. Chemical and immunological properties of galactomannans obtained from Histoplasma duboisii, Histoplasma capsulatum, Paracoccidioides brasiliensis and Blastomyces dermatitidis. Mycopathol Mycol Appl. 1974;54(1):111-25. https://doi.org/10.1007/bf02055979.

63. Buffo J, Herman MA, Soll DR. A characterization of $\mathrm{pH}-$ regulated dimorphism in Candida albicans. Mycopathologia. 1984;85(1):21-30. https://doi.org/10.1007/ bf00436698.

64. Kennedy MJ, Rogers AL, Hanselmen LR, Soll DR, Yancey RJ. Variation in adhesion and cell surface hydrophobicity in Candida albicans white and opaque phenotypes. Mycopathologia. 1988;102(3):149-56. https://doi.org/10. 1007/bf00437397.

65. Nishimura K, Miyaji M. Studies on a saprophyte of $E x$ ophiala dermatitidis isolated from a humidifier. Mycopathologia. 1982;77(3):173-81. https://doi.org/10.1007/ bf00518803.

66. Huppert M, Sun SH, Harrison JL. Morphogenesis throughout saprobic and parasitic cycles of Coccidioides immitis. Mycopathologia. 1982;78(2):107-22. https://doi. org/10.1007/bf00442634.

67. Sabie FT, Gadd GM. Effect of nucleosides and nucleotides and the relationship between cellular adenosine $3^{\prime}: 5^{\prime}$ cyclic monophosphate (cyclic AMP) and germ tube formation in Candida albicans. Mycopathologia. 1992;119(3):147-56. https://doi.org/10.1007/bf00448812.

68. Tilden EB, Hatton EH, Freeman S, Williamson WM, Koenig VL. Preparation and properties of the endotoxins of Aspergillus fumigatus and Aspergillus flavus. Mycopathol Mycol Appl. 1961;14(4):325-46. https://doi.org/ 10.1007/bf02051548

69. Aoki S, Ito-Kuwa S, Nakamura K, Kato J, Ninomiya K, Vidotto V. Extracellular proteolytic activity of Cryptococcus neoformans. Mycopathologia. 1994;128(3):143-50. https://doi.org/10.1007/bf01138475. 
70. Vidotto V, Sinicco A, Di Fraia D, Cardaropoli S, Aoki S, Ito-Kuwa S. Phospholipase activity in Cryptococcus neoformans. Mycopathologia. 1996;136(3):119-23. https:// doi.org/10.1007/bf00438916.

71. Shah DT, Larsen B. Clinical isolates of yeast produce a gliotoxin-like substance. Mycopathologia. 1991;116(3): 203-8. https://doi.org/10.1007/bf00436836.

72. Reeves EP, Messina CGM, Doyle S, Kavanagh K. Correlation between gliotoxin production and virulence of Aspergillus fumigatus in Galleria mellonella. Mycopathologia. 2004;158(1):73-9. https://doi.org/10.1023/b: myco.0000038434.55764.16.

73. Kumar CPG, Kumar SSJ, Menon T. Phospholipase and proteinase activities of clinical isolates of Candida from immunocompromised patients. Mycopathologia. 2006;161(4):213-8. https://doi.org/10.1007/s11046-0050157-4.

74. Rosas ÁL, Casadevall A. Melanization decreases the susceptibility of Cryptococcus neoformans to enzymatic degradation. Mycopathologia. 2001;151(2):53-6. https:// doi.org/10.1023/a:1010977107089.

75. Isola D, Selbmann L, de Hoog GS, Fenice M, Onofri S, Prenafeta-Boldú FX, et al. Isolation and screening of black fungi as degraders of volatile aromatic hydrocarbons. Mycopathologia. 2013;175(5):369-79. https://doi.org/10. 1007/s11046-013-9635-2.

76. Staib F. Proteolysis and pathogenicity of Candida albicans strains. Mycopathol Mycol Appl. 1969;37(4):345-8. https://doi.org/10.1007/bf02129881.

77. Yike I. Fungal proteases and their pathophysiological effects. Mycopathologia. 2011;171(5):299-323. https:// doi.org/10.1007/s11046-010-9386-2.

78. Moyes DL, Wilson D, Richardson JP, Mogavero S, Tang $\mathrm{SX}$, Wernecke $\mathrm{J}$, et al. Candidalysin is a fungal peptide toxin critical for mucosal infection. Nature. 2016;532:64. https://doi.org/10.1038/nature17625.

79. Slutsky B, Buffo J, Soll D. High-frequency switching of colony morphology in Candida albicans. Science. 1985;230(4726):666-9. https://doi.org/10.1126/science. 3901258.

80. Giraldo R, Angela R, Gutiérrez F, Robledo M, Londoño F, Hernández $\mathrm{H}$, et al. Pathogenesis of paracoccidioidomycosis: A model based on the study of 46 patients. Mycopathologia. 1976;58(2):63-70. https://doi.org/10.1007/ bf00707174.

81. Arango M, Yarzábal L. T-cell dysfunction and hyperimmunoglobulinemia E in paracoccidioidomycosis. Mycopathologia. 1982;79(2):115-23. https://doi.org/10.1007/ bf00468089.

82. Arango M, Oropeza F, Anderson O, Contreras C, Bianco N, Yarzàbal L. Circulating immune complexes and in vitro cell reactivity in paracoccidioidomycosis. Mycopathologia. 1982;79(3):153-8. https://doi.org/10.1007/bf01837195.

83. Benard G. An overview of the immunopathology of human paracoccidioidomycosis. Mycopathologia. 2008;165(4): 209-21. https://doi.org/10.1007/s11046-007-9065-0.

84. Alteras I, Saryt E. Prevalence of pathogenic fungi in the toe-webs and toe-nails of diabetic patients. Mycopathologia. 1979;67(3):157-9. https://doi.org/10.1007/ bf00470749.
85. Vélez H, Díaz F. Onychomycosis due to saprophytic fungi. Mycopathologia. 1985;91(2):87-92. https://doi.org/10. 1007/bf00436541.

86. Godoy P, Nunes F, Silva V, Tomimori-Yamashita J, Zaror L, Fischman O. Onychomycosis caused by Fusarium solani and Fusarium oxysporum in São Paulo, Brazil. Mycopathologia. 2004;157(3):287-90. https://doi.org/10. 1023/B:MYCO.0000024186.32367.d4.

87. Gupta AK, Cooper EA. Update in antifungal therapy of dermatophytosis. Mycopathologia. 2008;166(5):353-67. https://doi.org/10.1007/s11046-008-9109-0.

88. Uribe-J F, Zuluaga AI, Leon W, Restrepo A. Histopathology of chromoblastomycosis. Mycopathologia. 1989;105(1):1-6. https://doi.org/10.1007/bf00443822.

89. Silva JP, de Souza W, Rozental S. Chromoblastomycosis: a retrospective study of 325 cases on Amazonic Region (Brazil). Mycopathologia. 1998;143(3):171-5. https://doi. org/10.1023/a:1006957415346.

90. Queiroz-Telles F, Santos DW. Challenges in the therapy of chromoblastomycosis. Mycopathologia. 2013;175(5):477-88. https://doi.org/10.1007/s11046-0139648-x.

91. Lyon JP, Pedroso e Silva Azevedo CM, Moreira LM, de Lima CJ, de Resende MA. Photodynamic antifungal therapy against chromoblastomycosis. Mycopathologia. 2011;172(4):293-7. https://doi.org/10.1007/s11046-0119434-6.

92. Queiroz-Telles F, de Hoog S, Santos DWCL, Salgado CG, Vicente VA, Bonifaz A, et al. Chromoblastomycosis. Clin Microbiol Rev. 2017;30(1):233-76. https://doi.org/10. 1128/cmr.00032-16.

93. Martins N, Ferreira ICFR, Barros L, Silva S, Henriques M. Candidiasis: predisposing factors, prevention, diagnosis and alternative treatment. Mycopathologia. 2014;177(5):223-40. https://doi.org/10.1007/s11046-0149749-1.

94. Jadhav VJ, Pal M, Mishra GS. Etiological significance of Candida albicans in otitis externa. Mycopathologia. 2003;156(4):313-5. https://doi.org/10.1023/b:myco. 0000003574.89032 .99 .

95. Satoh K, Makimura K, Hasumi Y, Nishiyama Y, Uchida $\mathrm{K}$, Yamaguchi H. Candida auris sp. nov., a novel ascomycetous yeast isolated from the external ear canal of an inpatient in a Japanese hospital. Microbiol Immunol. 2009;53(1):41-4.

96. Rozenbaum R, Gonçalves AJR, Wanke B, Caiuby MJ, Clemente H, Lazera MdS, et al. Cryptococcus neoformans varieties as agents of cryptococcosis in Brazil. Mycopathologia. 1992;119(3):133-6. https://doi.org/10.1007/ bf00448809.

97. Chen Y, Che F, Chen J, Wei F, Xu N, Yang M, et al. Cryptococcosis in China (1985-2010): review of cases from Chinese database. Mycopathologia. 2012;173(5):329-35. https://doi.org/10.1007/s11046-011-9471-1.

98. Xi L, Lu C, Zhou X, Wang L, Xie S. Fifteen cases of penicilliosis in Guangdong, China. Mycopathologia. 2004;158(2):151-5. https://doi.org/10.1023/b:myco. 0000041842.90633 .86$.

99. Hu Y, Zhang J, Li X, Yang Y, Zhang Y, Ma J, et al. Penicillium marneffei infection: an emerging disease in 
mainland China. Mycopathologia. 2013;175(1):57-67. https://doi.org/10.1007/s11046-012-9577-0.

100. Shaukat A, Bakri F, Young P, Hahn T, Ball D, Baer MR, et al. Invasive filamentous fungal infections in allogeneic hematopoietic stem cell transplant recipients after recovery from neutropenia: clinical, radiologic, and pathologic characteristics. Mycopathologia. 2005;159(2):181-8. https://doi.org/10.1007/s11046-004-5495-0.

101. Blair JE, Coakley B, Santelli AC, Hentz JG, Wengenack NL. Serologic testing for symptomatic coccidioidomycosis in immunocompetent and immunosuppressed hosts. Mycopathologia. 2006;162(5):317. https://doi.org/10. 1007/s11046-006-0062-5.

102. Thompson GR, Wiederhold NP. Isavuconazole: a comprehensive review of spectrum of activity of a new triazole. Mycopathologia. 2010;170(5):291-313. https://doi. org/10.1007/s11046-010-9324-3.

103. Rogers AL, Beneke ES. Human pathogenic fungi recovered from Brasilian soil. Mycopathol Mycol Appl. 1964;22(1):15-20. https://doi.org/10.1007/bf02058729.

104. Dabrowa N, Landau JW, Newcomer VD, Plunkett OA. A survey of tide-washed coastal areas of southern California for fungi potentially pathogenic to man. Mycopathol Mycol Appl. 1964;24(2):137-50. https://doi.org/10.1007/ bf02075556.

105. Abdel-Hafez SII. Survey of the mycoflora of desert soils in Saudi Arabia. Mycopathologia. 1982;80(1):3-8. https:// doi.org/10.1007/bf00437171.

106. Mercantini R, Marsella R, Cervellati MC. Keratinophilic fungi isolated from Antarctic soil. Mycopathologia. 1989;106(1):47-52. https://doi.org/10.1007/bf00436926.

107. Ajello L. Natural history of the dermatophytes and related fungi. Mycopathol Mycol Appl. 1974;53(1):93-110. https://doi.org/10.1007/bf02127200.

108. Sinski JT, Flouras K. A survey of dermatophytes isolated from human patients in the United States from 1979 to 1981 with chronological listings of worldwide incidence of five dermatophytes often isolated in the United States. Mycopathologia. 1984;85(1):97-120. https://doi.org/10. 1007/bf00436709.

109. Burge HP, Boise JR, Rutherford JA, Solomon WR. Comparative recoveries of airborne fungus spores by viable and non-viable modes of volumetric collection. Mycopathologia. 1977;61(1):27-33. https://doi.org/10. 1007/bf00440755.

110. Takahashi T. Airborne fungal colony-forming units in outdoor and indoor environments in Yokohama, Japan. Mycopathologia. 1997;139(1):23-33. https://doi.org/10. 1023/a:1006831111595.

111. Rainer J, Peintner U, Pöder R. Biodiversity and concentration of airborne fungi in a hospital environment. Mycopathologia. 2001;149(2):87-97. https://doi.org/10. 1023/a:1007273131130.

112. Nielsen KF, Huttunen K, Hyvärinen A, Andersen B, Jarvis BB, Hirvonen M-R. Metabolite profiles of Stachybotrys isolates from water-damaged buildings and their induction of inflammatory mediators and cytotoxicity in macrophages. Mycopathologia. 2002;154(4):201-5. https://doi. org/10.1023/a:1016383402963.

113. Littman ML, Borok R. Relation of the pigeon to cryptococcosis: natural carrier state, heat resistance and survival of Cryptococcus neoformans. Mycopathol Mycol Appl. 1968;35(3):329-45. https://doi.org/10.1007/bf02050749.

114. Bartlett KH, Cheng P-Y, Duncan C, Galanis E, Hoang L, Kidd S, et al. A decade of experience: Cryptococcus gattii in British Columbia. Mycopathologia. 2012;173(5):311-9. https://doi.org/10.1007/s11046-011-9475-x.

115. Ajello L, Briceño-Maaz T, Campins H, Moore JC. Isolation of Histoplasma capsulatum from an oil bird (Steatornis caripensis) cave in Venezuela. Mycopathol Mycol Appl. 1960;12(3):199-206. https://doi.org/10. 1007/bf02051369.

116. Apinis AE, Pugh GJF. Thermophilous fungi of birds' nests. Mycopathol Mycol Appl. 1967;33(1):1-9. https:// doi.org/10.1007/bf02049784.

117. Ajello L, Padhye AA, Sukroongreung S, Nilakul CH, Tantimavanic S. Occurrence of Penicillium marneffei infections among wild bamboo rats in Thailand. Mycopathologia. 1995;131(1):1-8. https://doi.org/10.1007/ bf01103897.

118. Nishimura K, Miyaji M, Taguchi H, Tanaka R. Fungi in bathwater and sludge of bathroom drainpipes. Mycopathologia. 1987;97(1):17-23. https://doi.org/10.1007/ bf00437326.

119. Melo dos Santos V, Dorner JW, Carreira F. Isolation and toxigenicity of Aspergillus fumigatus from moldy silage. Mycopathologia. 2003;156(2):133-8. https://doi.org/10. 1023/a:1022996911563.

120. Conant NF. The taxonomy of the anascosporous yeast-like fungi. Mycopathologia. 1939;2(1):253-66. https://doi.org/ $10.1007 / \mathrm{bf00436291.}$

121. Lodder J, de Vries NF. Some notes on Torulopsis glabrata (Anderson) nov. comb. Mycopathologia. 1938;1(2):98-103. https://doi.org/10.1007/bf00440852.

122. Diddens HA, Lodder J. On some sporogenous yeasts and their imperfect stages. Mycopathologia. 1940;2(4):28-36. https://doi.org/10.1007/bf00450240.

123. Lodder J. Torulopsis or Cryptococcus? Mycopathologia. 1938;1(1):62-7. https://doi.org/10.1007/bf00440372.

124. Diddens HA, Lodder J. An appeal for unification of the generic taxonomy in the Mycotoruloideae. Mycopathologia. 1940;2(4):1-6. https://doi.org/10.1007/bf00450237.

125. Xu J. Fungal DNA barcoding. Genome. 2016;59(11): 913-32. https://doi.org/10.1139/gen-2016-0046.

126. Cooke WB. A taxonomic study in the "black yeasts". Mycopathol Mycol Appl. 1962;17(1):1-43. https://doi. org/10.1007/bf02279261.

127. Tsuchiya T, Fukazawa Y, Taguchi M, Nakase T, Shinoda T. Serologic aspects on yeast classification. Mycopathol Mycol Appl. 1974;53(1):77-92. https://doi.org/10.1007/ bf02127199.

128. Gräser Y, Scott J, Summerbell R. The new species concept in dermatophytes - a polyphasic approach. Mycopathologia. 2008;166(5):239-56. https://doi.org/10.1007/s11046008-9099-y.

129. de Hoog GS, Dukik K, Monod M, Packeu A, Stubbe D, Hendrickx M, et al. Toward a novel multilocus phylogenetic taxonomy for the dermatophytes. Mycopathologia. 2017;182(1):5-31. https://doi.org/10.1007/s11046-0160073-9.

130. Hibbett D, Abarenkov K, Kõljalg U, Öpik M, Chai B, Cole $\mathrm{J}$, et al. Sequence-based classification and identification of 
fungi. Mycologia. 2016;108(6):1049-68. https://doi.org/ 10.3852/16-130.

131. Emmons CW. Trichophyton mentagrophytes (Pinoyella simii) isolated from dermatophytosis in the monkey. Mycopathologia. 1939;2(1):317-9. https://doi.org/10. 1007/bf00436293.

132. Cafarchia C, Gallo S, Capelli G, Otranto D. Occurrence and population size of Malassezia spp. in the external ear canal of dogs and cats both healthy and with otitis. Mycopathologia. 2005;160(2):143-9. https://doi.org/10. 1007/s11046-005-0151-x.

133. Brilhante RSN, Cavalcante CSP, Soares-Junior FA, Cordeiro RA, Sidrim JJC, Rocha MFG. High rate of $\mathrm{Mi}$ crosporum canis feline and canine dermatophytoses in Northeast Brazil: epidemiological and diagnostic features. Mycopathologia. 2003;156(4):303-8. https://doi.org/10. 1023/b:myco.0000003582.67122.69.

134. Mancianti F, Nardoni S, Cecchi S, Corazza M, Taccini F. Dermatophytes isolated from symptomatic dogs and cats in Tuscany, Italy during a 15-year-period. Mycopathologia. 2003;156(1):13-8. https://doi.org/10.1023/a: 1021361001794.

135. Nardoni S, Mancianti F, Corazza M, Rum A. Occurrence of Malassezia species in healthy and dermatologically diseased dogs. Mycopathologia. 2004;157(4):383-8. https://doi.org/10.1023/B:MYCO.0000030416.36743.dd.

136. Schubach TMP, de Oliveira Schubach A, Reis RSd, CuzziMaya T, Blanco TCM, Monteiro DF, et al. Sporothrix schenckii isolated from domestic cats with and without sporotrichosis in Rio de Janeiro, Brazil. Mycopathologia. 2002;153(2):83-6. https://doi.org/10.1023/a: 1014449621732 .

137. Cafarchia C, Camarda A, Romito D, Campolo M, Quaglia NC, Tullio D, et al. Occurrence of yeasts in cloacae of migratory birds. Mycopathologia. 2006;161(4):229-34. https://doi.org/10.1007/s11046-005-0194-Z.

138. Abegg MA, Cella FL, Faganello J, Valente P, Schrank A, Vainstein MH. Cryptococcus neoformans and Cryptococcus gattii isolated from the excreta of Psittaciformes in a Southern Brazilian Zoological Garden. Mycopathologia. 2006;161(2):83-91. https://doi.org/10.1007/s11046-0050186-z.

139. Ghosh PN, Fisher MC, Bates KA. Diagnosing emerging fungal threats: a one health perspective. Front Genet. 2018;9:376. https://doi.org/10.3389/fgene.2018.00376.

140. Fisher MC, Hawkins NJ, Sanglard D, Gurr SJ. Worldwide emergence of resistance to antifungal drugs challenges human health and food security. Science. 2018;360(6390): 739-42. https://doi.org/10.1126/science.aap7999.

141. Baldacci E. The classification of actinomycetes at the 3rd International Congress of Microbiology. Mycopathologia. 1941;3(1):42-3. https://doi.org/10.1007/bf00590097.

142. Emmons CW. Cryptococcus neoformans strains from a severe outbreak of bovine mastitis. Mycopathol Mycol Appl. 1952;6(3):231-4. https://doi.org/10.1007/bf02081436.

143. Fell JW, Meyer SA. Systematics of yeast species in the Candida parapsilosis group. Mycopathol Mycol Appl. 1967;32(3):177-93. https://doi.org/10.1007/bf02049795.

144. Joffe AZ. A modern system of Fusarium taxonomy. Mycopathol Mycol Appl. 1974;53(1):201-28. https://doi. org/10.1007/bf02127209.
145. de Capriles CH, Mata S, Middelveen M. Preservation of fungi in water (Castellani): 20 years. Mycopathologia. 1989;106(2):73-9. https://doi.org/10.1007/bf00437084.

146. Iwatsu T, Miyaji M, Okamoto S. Isolation of Phialophora verrucosa and Fonsecaea pedrosoi from nature in Japan. Mycopathologia. 1981;75(3):149-58. https://doi.org/10. 1007/bf00482809.

147. Aspiroz C, Moreno L-A, Rezusta A, Rubio C. Differentiation of three biotypes of Malassezia species on human normal skin. Correspondence with M. globosa, M. sympodialis and M. restricta. Mycopathologia. 1999;145(2):69-74. https://doi.org/10.1023/a:1007017917230.

148. Vismer HF, Hull PR. Prevalence, epidemiology and geographical distribution of Sporothrix schenckii infections in Gauteng, South Africa. Mycopathologia. 1997;137(3): 137-43. https://doi.org/10.1023/a:1006830131173.

149. Mendoza L, Villalobos J, Calleja CE, Solis A. Evaluation of two vaccines for the treatment of pythiosis insidiosum in horses. Mycopathologia. 1992;119(2):89-95. https://doi. org/10.1007/bf00443939.

150. Van den Bogart HGG, Van den Ende G, Van Loon PCC, Van Griensven LJLD. Mushroom worker's lung: Serologic reactions to thermophilic actinomycetes present in the air of compost tunnels. Mycopathologia. 1993;122(1):21-8. https://doi.org/10.1007/bf01103705.

151. Hiruma M, Kawada A, Yoshida M, Kouya M. Hyperthermic treatment of chromomycosis with disposable chemical pocket warmers. Mycopathologia. 1993;122(2):107-14. https://doi.org/10.1007/bf01103608.

152. Martinez-Rossi NM, Peres NTA, Rossi A. Antifungal resistance mechanisms in dermatophytes. Mycopathologia. 2008;166(5):369-83. https://doi.org/10.1007/s11046008-9110-7.

153. Aspiroz C, Ara M, Varea M, Rezusta A, Rubio C. Isolation of Malassezia globosa and M. sympodialis from patients with pityriasis versicolor in Spain. Mycopathologia. 2002;154(3):111-7. https://doi.org/10.1023/A: 1016020209891.

154. de Camargo ZP. Serology of paracoccidioidomycosis. Mycopathologia. 2008;165(4):289-302. https://doi.org/ 10.1007/s11046-007-9060-5.

155. Gokce G, Cerikcioglu N, Yagci A. Acid proteinase, phospholipase, and biofilm production of Candida species isolated from blood cultures. Mycopathologia. 2007;164(6):265-69. https://doi.org/10.1007/s11046-0079053-4.

156. Gupta N, Haque A, Lattif AA, Narayan RP, Mukhopadhyay G, Prasad R. Epidemiology and molecular typing of Candida isolates from burn patients. Mycopathologia. 2004;158(4):397-405. https://doi.org/10.1007/s11046004-1820-x.

157. Ali-Shtayeh MS, Khaleel TKM, Jamous RM. Ecology of dermatophytes and other keratinophilic fungi in swimming pools and polluted and unpolluted streams. Mycopathologia. 2003;156(3):193-205. https://doi.org/10. 1023/a:1023311411004.

158. Negri M, Martins M, Henriques M, Svidzinski TI, Azeredo J, Oliveira R. Examination of potential virulence factors of Candida tropicalis clinical isolates from hospitalized patients. Mycopathologia. 2010;169(3):175-82. https:// doi.org/10.1007/s11046-009-9246-0 